Article

\title{
The Effect of Embodied Impact on the Cost-Optimal Levels of Nearly Zero Energy Buildings: A Case Study of a Residential Building in Thessaloniki, Greece
}

\author{
Panagiotis Chastas *, Theodoros Theodosiou, Karolos J. Kontoleon and Dimitrios Bikas \\ Aristotle University of Thessaloniki, Department of Civil Engineering, Laboratory of Building Construction and \\ Building Physics, Thessaloniki 54124, Greece; tgt@civil.auth.gr (T.T.); kontoleon@civil.auth.gr (K.J.K.); \\ bikasd@civil.auth.gr (D.B.) \\ * Correspondence: pchastas@civil.auth.gr; Tel.: +30-231-099-5818
}

Academic Editor: Hongyu Wu

Received: 22 March 2017; Accepted: 16 May 2017; Published: 24 May 2017

\begin{abstract}
Considering the nearly zero energy building (nZEB) and the increased measures for the improvement of the energy efficiency, the international literature indicates an extended use of specialized materials and technical installations. An increase in the embodied energy follows that use, with a final share between $74 \%$ and $100 \%$ in the total life cycle energy of residential nZEBs. The current energy efficiency legislation considers only the impact from the operational phase and ignores the embodied impact from the remaining life cycle phases of the building. Nevertheless, the delegated regulation 244 of 2012 acknowledges the incompleteness of this assessment and provides an optional consideration of the embodied ("grey") energy. The current study applies this option through the macroeconomic global cost calculations and the cost-optimal levels of nZEBs. The results indicate a limited effect of the embodied impact on the cost-optimal levels and in specific on extended calculation periods and in combination with other key parameters of the sensitivity analysis. An increase in the primary energy and a transposition to variants with lower use of materials and decreased embodied emissions follow this effect. Sensitivity analysis confirms the calculation period as a key parameter and indicates the need for further research.
\end{abstract}

Keywords: embodied impact; $\mathrm{CO}_{2}$ emissions; $\mathrm{EPBD}$ recast; $\mathrm{nZEB}$; cost-optimal levels

\section{Introduction}

The European Union in 2010 enhanced the framework for the reduction of energy consumption and emissions in the building sector, via the recast of the European Directive 2010/31/EE [1], the Delegated Regulation 244/2012 [2] and the accompanying guidelines [3]. This reinforcement of the regulations for the energy efficiency of buildings focuses on the energy and the emissions related to the operating phase of the building's life cycle. Literature reviews which concern conventional, low energy, passive and nearly zero energy buildings [4-7], indicate a reduction of the operating energy. A respective increase in the embodied energy and for the life cycle energy analysis (LCEA) perspective follows that reduction. The final share of the embodied energy in the total life cycle energy of residential buildings ranges between $74 \%$ and $100 \%$ when the zero energy target is achieved [7]. The extended use of materials and technical installations [8] identifies the increased initial, recurring [9] and "overlooked" [10] embodied energy and leads to proposals for accounting embodied energy in the life cycle (LC-ZEB) and rating (LC-BER) of nearly zero energy buildings [11] or even for the consideration of the environmental impact on monetary values and also of the environmental savings for the sustainability assessment of retrofitting measures for residential buildings [12].

In particular, the Building Sustainability Assessment Tools (BSATs) and the national regulations acknowledge the embodied environmental impact and provide its evaluation through their certification 
framework by various direct and indirect approaches. In Switzerland, the Minergie A standard, which launched in 2011 as a step closer to the definition of the nearly zero energy building, provides a life cycle approach to the energy efficiency of buildings and also a limit value for embodied energy as a precondition for the certification [13]. Also, Building Research Establishment and Environmental Assessment Method (BREEAM) [14] and Code for Sustainable Homes (CSH) [15], assess the management, energy, water, waste, transportation etc. and additionally address a whole Life Cycle Assessment (LCA) as a way to a high rated certification [14]. At this point, it is important to mention that the majority of BSATs, addresses the environmental impact through a qualitative approach by awarding a good practice via a credit point system. Even though when a whole LCA has been conducted, the quantified results in embodied energy for CSH and Deutsche Gesellschaft für Nachhaltiges Bauen (DGNB) $[15,16]$, in carbon emissions with the global warming potential impact category for BREEAM, DGNB, Sustainable Building Toll for Portugal (SBTool ${ }^{\mathrm{PT}}$ ) and Comprehensive Assessment System for Building Environmental Efficiency (CASBEE) [17-20] or even more in a range of impact indicators for CSH, DGNB and SBTool ${ }^{\mathrm{PT}}[15,18,19]$ such as the acidification potential, the eutrophication potential and the photochemical ozone creation, those are transformed in a qualitative form and awarded with a predefined number of credits. Along with the direct LCA, a variety of indirect considerations of the environmental impact have enhanced the life cycle thinking in the building industry, such as the use of certified materials through the Environmental Product Declaration (EPD) system [14,21], materials with a responsible and recognized extraction and sourcing [21], with a low Global Warming Potential (GWP) effect [14] or even materials with an environmental or social standard recognition [22]. Moreover, the Building Sustainability Assessment Tools award the use of local materials, the reuse or recycling of materials, a demolition-construction and operation waste management plan [21,23], the convenience and minimization of the effort for disassembling the products at the end of their life cycle $[19,24]$ or even the extension of the building's lifespan through the service life of its structural materials and components [20]. Even though the environmental impact appears to be "embodied" in the framework of most BSATs, there is a deficiency on capturing the actual performance of the structures [25] along with a weighting set that promotes the energy efficiency and site impacts related decisions [26]. In most BSATs, the LCA is under-awarded by the weighting set with the highest weighting under 10\% [27]. Therefore, a different approach on the awarding of credits [25] or an adaptable weighting set may customise the system [28] and adjust it to the increasing importance of the embodied environmental impact.

Except for the national regulations and the Building Sustainability Assessment Tools, the current legislation for nearly zero energy buildings as defined by the recast of the European Directive 2010/31/EE, the Delegated Regulation 244/2012 and the accompanying guidelines is characterized by an incompleteness of the assessment, "as life cycle methodologies are not considered in detail on the EPBD (Energy Performance of Buildings Directive) recast" [29]. The calculations for the macroeconomic perspective consider the environmental impact in the form of greenhouse gas emissions and only for the operating phase of the building, with the transformation of $\mathrm{CO}_{2}$ emissions into monetary values. Nevertheless, the accompanying guidelines of the delegated regulation 244/12 acknowledge the incompleteness of the assessment and provide an optional consideration of embodied ("grey") energy "as Member States are however free to extend the methodology towards full life cycle costing and might consider for this purpose also EN ISO 14040 [30], 14044 [31] and 14025 [32]" [3].

The scope of this study is to extend the framework for the cost-optimal levels of nearly zero energy buildings to a whole life cycle assessment and cost approach. The final goal is to assess the potential effect of the embodied environmental impact on the cost-optimal levels of nearly zero energy residential buildings and identify the most significant parameters affecting the final result. 


\section{Materials and Methods}

\subsection{Case Study Reference Building}

Recent reports state that the Greek Government has not fulfilled the obligation for the definition of nearly zero energy buildings, the cost-optimal levels and the reference buildings [33,34]. Therefore, a statistical analysis of the Greek residential building stock [35] and especially for the regions that compose the climatic area C [36], provided the case study reference/representative building. The outcome of the statistical analysis is a residential building with a total area of $191.10 \mathrm{~m}^{2}$ and a heated floor area of $123.75 \mathrm{~m}^{2}$ (Table 1). The building is a "representative" example of the Greek building construction for single-family buildings in the city of Thessaloniki. Nevertheless, it should not be confused with the Greek national reference residential building as its definition is still in progress by the Greek government.

Table 1. Main features of the case study reference building.

\begin{tabular}{cc}
\hline Building Features & Value \\
\hline Total area $\left(\mathrm{m}^{2}\right)$ & 191.10 \\
Heated (reference) area $\left(\mathrm{m}^{2}\right)$ & 123.75 \\
Non-heated area $\left(\mathrm{m}^{2}\right)$ & 34.86 \\
Pilotis-open area $\left(\mathrm{m}^{2}\right)$ & 32.49 \\
External wall area $\left(\mathrm{m}^{2}\right)$ & 210.11 \\
Fenestration area $\left(\mathrm{m}^{2}\right)$ & 31.37 \\
Window to wall ratio $(\%)$ & 14.93 \\
\hline
\end{tabular}

In particular, the building is located in climatic area $\mathrm{C}$ of Greece and more specifically in northern Greece and the city of Thessaloniki, at a latitude of $40^{\circ} 31^{\prime}$, a longitude of $22^{\circ} 58^{\prime}$ and an altitude of $4.0 \mathrm{~m}$. The current study considers a heating period of 181 days, a cooling period of 184 days and a south orientation. It is a two storey single-family house designed for six occupants (Figures 1-3) in an urban area of Thessaloniki. It has three bedrooms, two living rooms with a kitchen, two bathrooms, a small Water Closet (WC)-toilet, a room for the Heating Ventilation and Air-Conditioning (HVAC) equipment and a garage (pilotis). Furthermore, the building has a structural frame of reinforced concrete and is dimensioned according to the minimum requirements of the current Greek national building construction and energy efficiency regulations. It is composed of two heated zones (ground and first floor) and two non-heated zones (staircase and HVAC equipment room). The vertical opaque elements of the building envelope are insulated with an external layer of $7 \mathrm{~cm}$ of extruded polystyrene (XPS) and also a final coating of plaster and paint for both the interior and exterior surfaces. The horizontal opaque elements (flat roof, floor over pilotis and ground floor) are insulated with a layer of $8 \mathrm{~cm}$ of extruded polystyrene (XPS), with a final exterior coating of concrete slabs, paint or gravel and an interior coating of paint or ceramic tiles respectively. The building elements which are in contact with the non-heated areas have an insulation thickness of $4 \mathrm{~cm}$. The fenestration is composed of polyvinyl chloride (PVC) windows with double glazing (4/6air/4). The reference/representative building is dimensioned for the minimum requirements of energy efficiency class B, according to the Greek Regulation for the Energy Efficiency of Buildings (KENAK) [37]. In addition, the energy requirements for the heating and the cooling of the building were calculated through dynamic energy simulation, with software Energy Plus [38] and the energy demand for the domestic hot water (DHW) was calculated according to the technical guides of KENAK [39], EN 15316-3-2 [40] and EN 15316-3-3 [41]. The building has natural ventilation and there is no consideration of the energy requirements for lighting, as indicated by the current Greek national legislation for residential buildings. The annual energy requirements are calculated according to KENAK and the recast of the European Directive 2010/31/EE for a square meter of the reference area, that for the current case study matches the heated floor area of the building. 


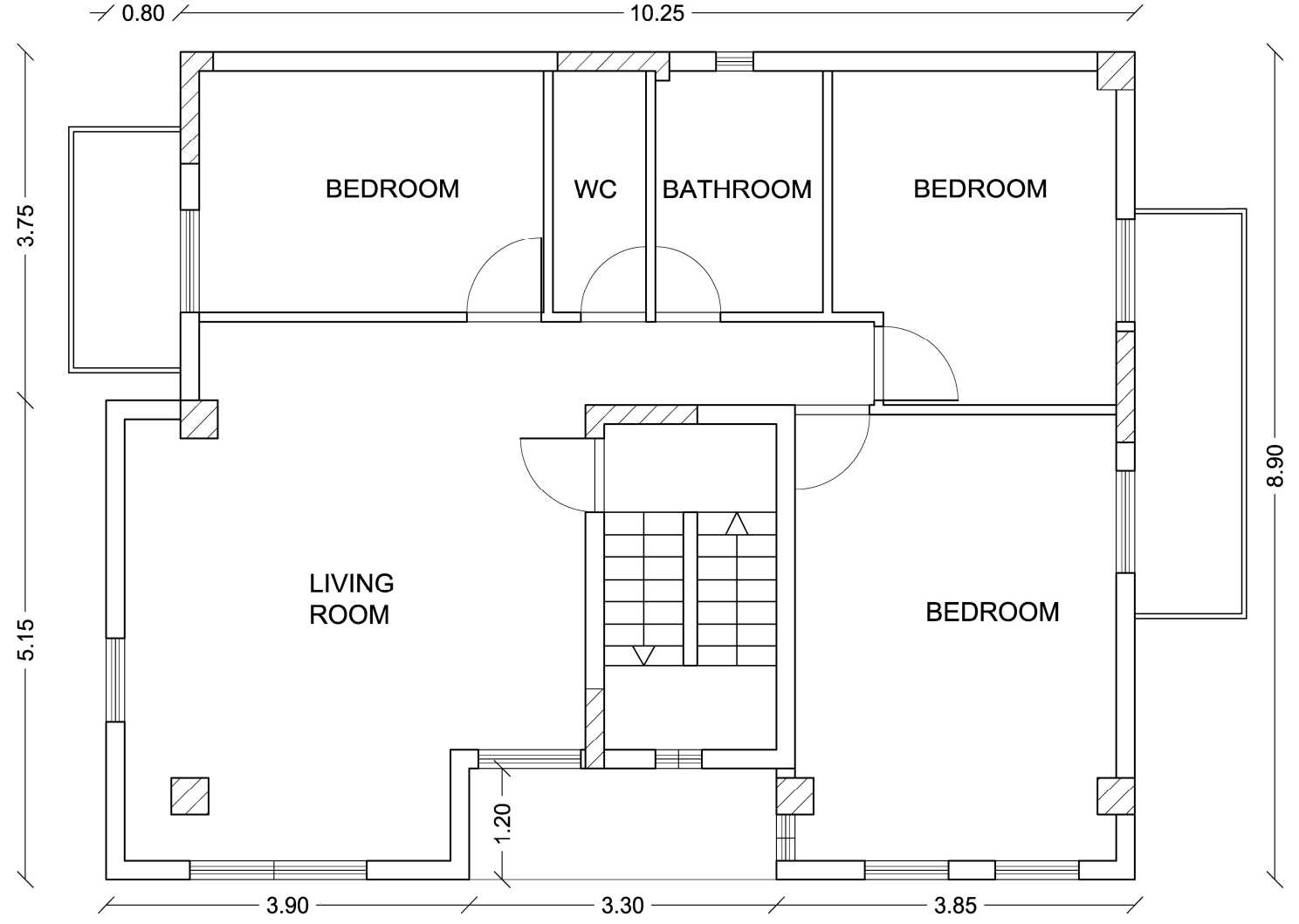

Figure 1. Case study reference building. First floor plan.

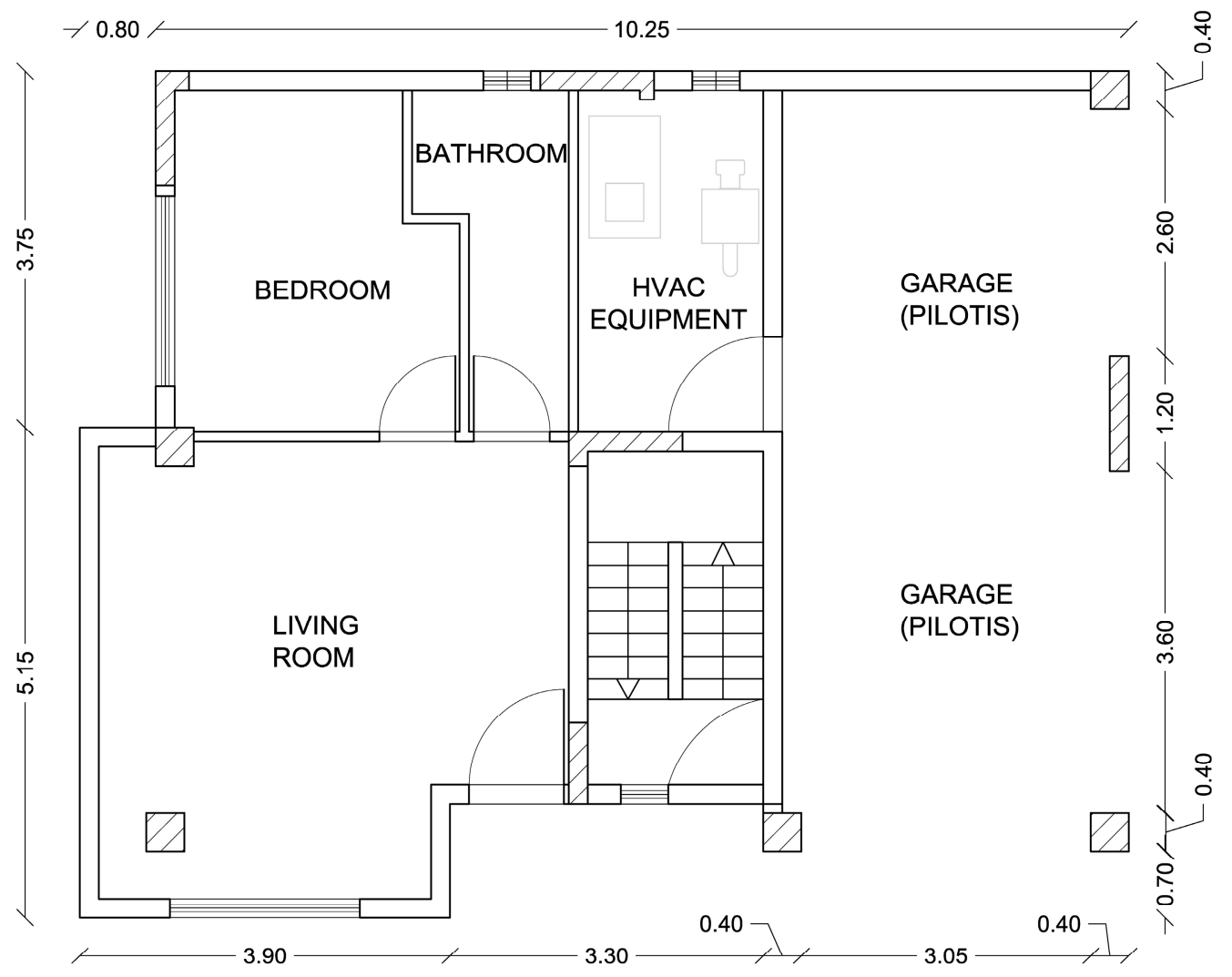

Figure 2. Case study reference building. Ground floor plan. 


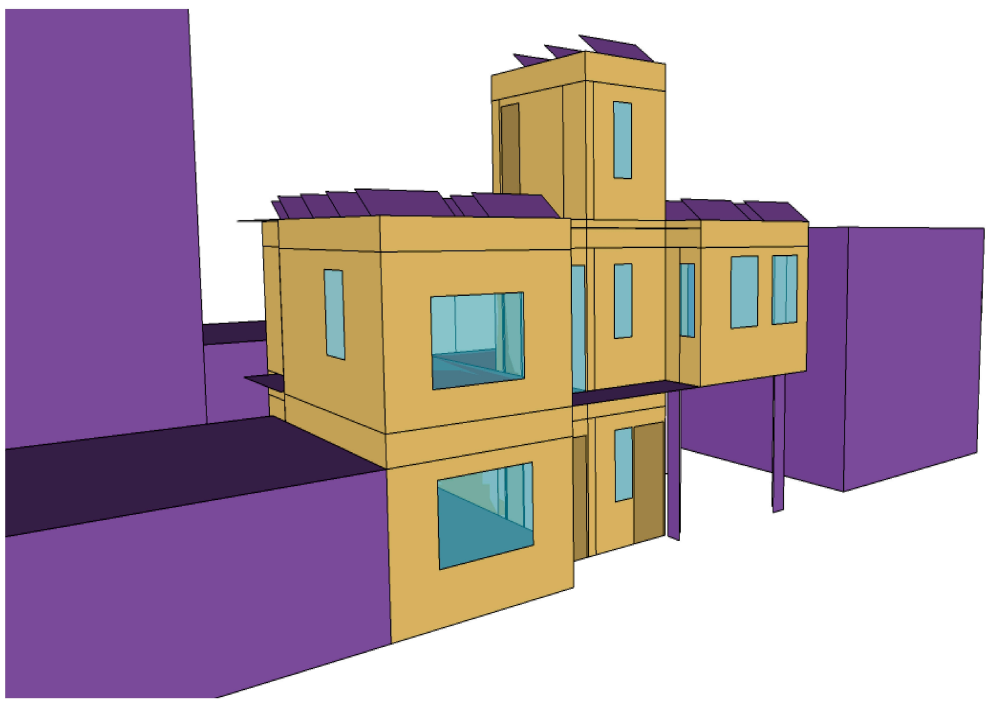

Figure 3. Case study reference building. 3D view.

A detailed presentation of the energy efficiency features and the energy demand of the reference building is presented in Table 2 and also in the following (Section 2.2.1 Energy Analysis). The total energy demand for the case study reference/representative building is $117.16 \mathrm{kWh} / \mathrm{m}^{2}$.annually (Table 2). The primary energy for the minimum requirements of the systems' efficiencies according to the Greek Regulation for the Energy Efficiency of Buildings and by considering the use of oil for the heating and the domestic hot water, electricity for the cooling and the national primary energy factors (Section 2.2.1 Energy Analysis), is calculated at $143.94 \mathrm{kWh} / \mathrm{m}^{2}$. annually, and within the range of the building stock for single family houses and climatic area $C$ (between $0 \mathrm{kWh} / \mathrm{m}^{2}$.annually for the A+ energy efficiency class/highest performance and about $626 \mathrm{kWh} / \mathrm{m}^{2}$.annually for the $\mathrm{G}$ energy efficiency class/lowest performance) [42]. According to statistical data of Energy Performance Certificates issued between 2011 and 2015 for the Greek residential building stock, the average primary energy consumption for single family houses, the climatic area $C$ of Greece and the energy efficiency class $B$, is $120 \mathrm{kWh} / \mathrm{m}^{2}$.annually [42]. These values refer to averages and the calculation of the building's energy consumption when issuing an Energy Performance Certificate is based on the monthly quasi-steady-state method, in contrast to the dynamic energy simulation of the current case study.

Table 2. Annual energy demand for the case study reference building.

\begin{tabular}{cc}
\hline Energy Demand & $\left.\mathbf{( \mathbf { k W h } / \mathbf { m } ^ { \mathbf { 2 } } \cdot \mathbf { a }} \mathbf{*}\right)$ \\
\hline Heating & 53.59 \\
Cooling & 33.27 \\
Domestic Hot Water & 30.30 \\
Total & 117.16 \\
\hline \multicolumn{2}{c}{ * a: annually. }
\end{tabular}

\subsection{Analysis}

For the analysis of the data and in order the case study reference/representative building to reach the nearly zero energy target and also to extend the already existed methodological framework of the recast of the European Directive 2010/31/EE into a whole life cycle approach, is considered extremely important to conduct three core calculation processes (Figure 4), which follow a prior design of the building variants and of the energy efficiency measures: 
- Energy Analysis: For the quantification of the energy demand for the heating, cooling, domestic hot water and the electricity production, the calculation of the consumption and generation of fuels and electricity and finally the primary energy consumption of the building's variants.

- Life Cycle Assessment (LCA): For the quantification of the embodied impact, through process analysis and for the whole life cycle of the building, in carbon dioxide emissions equivalent.

- Life Cycle Cost (LCC) Analysis: For the calculations of the initial, the running, the replacement, the energy, the carbon and the disposal costs, the residual value and finally the total global costs for the macroeconomic calculations and for both steps of the procedure (Section 2.3 Method).

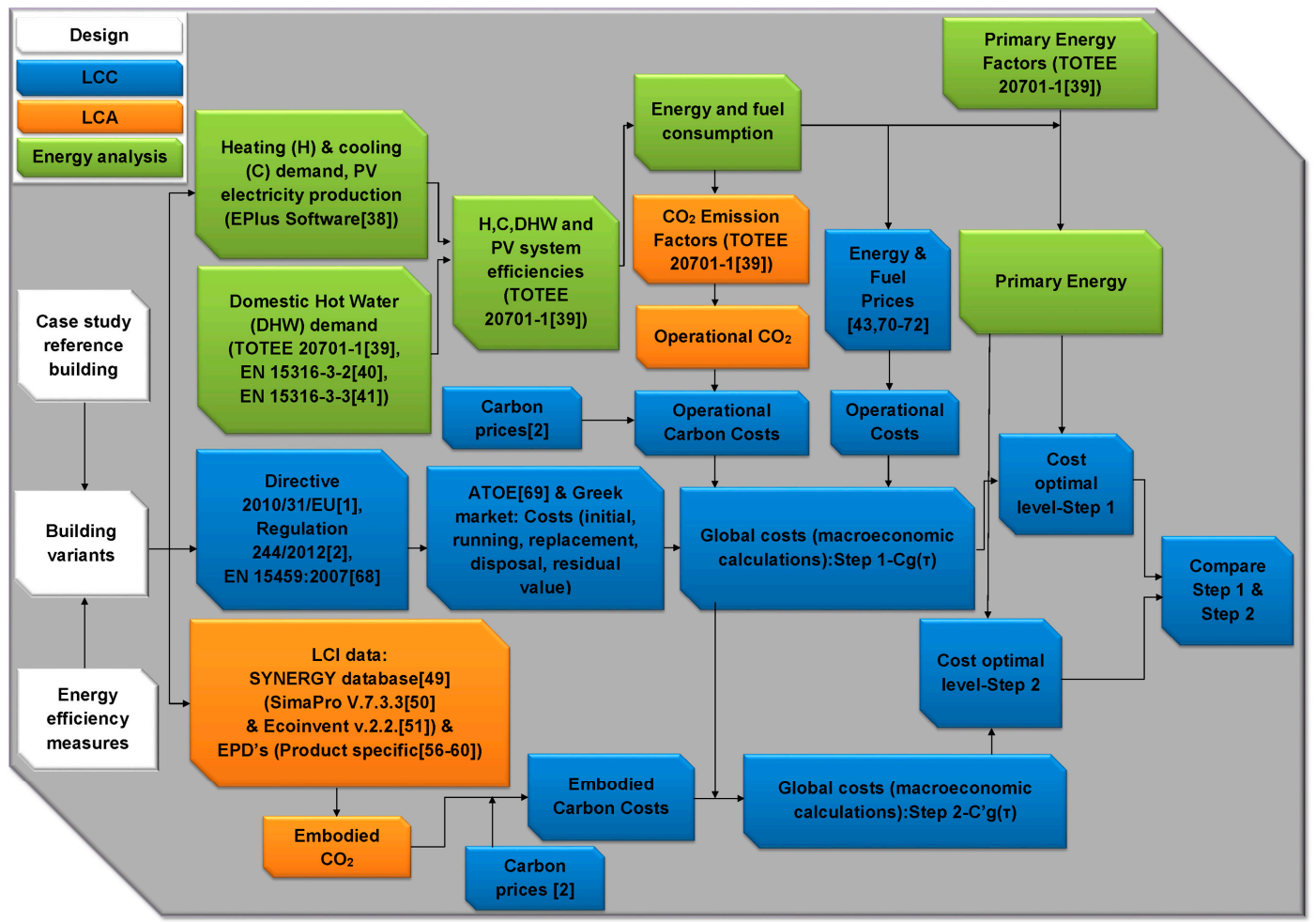

Figure 4. Analysis and correlation of the main core processes of the calculation procedure.

A detailed description of the calculation procedure follows in Section 2.2.1 Energy Analysis, Section 2.2.2 Life Cycle Assessment (LCA), Section 2.2.3 Life Cycle Cost (LCC) Analysis and Section 2.3 Method.

\subsubsection{Energy Analysis}

Concerning the energy analysis and in order the case study reference/representative building to reach the nearly zero energy target and also to define the cost-optimal levels, it is important to apply several energy efficiency measures, such as the increase in insulation thickness, energy efficient windows and photovoltaic panels (PV) for electricity production along with their combination in packages of measures and variants of the building. The energy analysis of the building and the electricity production from photovoltaic panels was conducted with software Energy Plus and through dynamic energy simulation. It should be mentioned that even though the minimum insulation requirements for climatic area $\mathrm{C}$ is $7 \mathrm{~cm}$ for the vertical and $8 \mathrm{~cm}$ for the horizontal opaque elements, the current analysis considers a range of insulation thickness between $3 \mathrm{~cm}$ (minimum U-value) and $14 \mathrm{~cm}$ (maximum U-value) (Table 3) with $1 \mathrm{~cm}$ step increase and by excluding $11 \mathrm{~cm}$ and $13 \mathrm{~cm}$ due to lack of availability in the Greek market in order to provide a full range of the global costs. The insulation is extruded polystyrene with a thermal conductivity coefficient $(\lambda)$ of $0.035(\mathrm{~W} / \mathrm{m} \cdot \mathrm{K})$. 
Table 3. Energy efficiency measures. Insulation thickness. Thermal transmittance (U-value) of the case study reference building and U-value range for the energy efficiency measures.

\begin{tabular}{|c|c|c|c|}
\hline Building Element & $\begin{array}{l}\text { Min U-Value } \\
\left(\mathrm{W} / \mathrm{m}^{2} \cdot \mathrm{K}\right)\end{array}$ & $\begin{array}{l}\text { Reference U-Value } \\
\left(\mathrm{W} / \mathrm{m}^{2} \cdot \mathrm{K}\right)\end{array}$ & $\begin{array}{l}\text { Max U-Value } \\
\left(\mathrm{W} / \mathrm{m}^{2} \cdot \mathrm{K}\right)\end{array}$ \\
\hline Wall of reinforced concrete & 0.866 & 0.387 & 0.233 \\
\hline Masonry of bricks & 0.685 & 0.346 & 0.217 \\
\hline Flat roof & 0.691 & 0.348 & 0.218 \\
\hline Ground floor & 0.742 & 0.613 & 0.402 \\
\hline Floor over pilotis & 0.825 & 0.379 & 0.230 \\
\hline Floor in contact with non-heated area & 0.726 & 0.601 & 0.397 \\
\hline $\begin{array}{l}\text { Wall of reinforced concrete in contact with } \\
\text { non-heated area }\end{array}$ & 0.800 & 0.651 & 0.418 \\
\hline Masonry of bricks in contact with non-heated area & 0.663 & 0.558 & 0.377 \\
\hline
\end{tabular}

For the fenestration of the building, were examined eight different types of windows with a variation in the glazing units and a standard PVC frame with a Uf value of $1.60\left(\mathrm{~W} / \mathrm{m}^{2} \cdot \mathrm{K}\right)$. The windows differentiate in the number of panes, the gas (air or argon) and the type of glass (flat or with low-e coating) (Table 4). The U value of doors is $1.40\left(\mathrm{~W} / \mathrm{m}^{2} \cdot \mathrm{K}\right)$ for all scenarios.

Table 4. Energy efficiency measures. Building fenestration. Average window thermal transmittance (Uw-value).

\begin{tabular}{cc}
\hline Window Glazing & Uw-Value $\left(\mathbf{W} / \mathbf{m}^{2} \cdot \mathbf{K}\right)$ \\
\hline W0: Reference (4/6air/4) & 2.74 \\
W1: 6/12air/6 & 2.56 \\
W2: 6/12argon/6 & 2.44 \\
W3: low-e 6/12air/6 & 1.95 \\
W4: 6/12air/6/12air/6 & 1.88 \\
W5: 6/12argon/6/12argon/6 & 1.78 \\
W6: low-e 6/12argon/6 & 1.76 \\
W7: low-e 6/12air/6/12air/6 & 1.61 \\
W8: low-e 6/12argon/6/12argon/6 & 1.47 \\
\hline
\end{tabular}

The difference in the total energy demand of the case study reference building and the alternative combinations of energy efficiency measures is described in detail in Table 5. The energy savings from the increase in insulation thickness and the energy efficient windows, with the highest value of $-22.01 \mathrm{kWh} / \mathrm{m}^{2}$.annually that reflects a total energy demand of $94.95 \mathrm{kWh} / \mathrm{m}^{2}$.annually indicate the need for the installation of photovoltaic panels for electricity production in order the case study reference/representative building to reach the nearly zero energy target. The simulation of electricity production from photovoltaic panels was conducted with the equivalent one diode method of software Energy Plus. The selected type of PV module with an area of $1.65 \mathrm{~m}^{2}$ provides in Standard Test Conditions $\left(\mathrm{S}_{\mathrm{TC}}\right)$ a maximum power $\left(\mathrm{P}_{\max }\right)$ of $250 \mathrm{Wp}$, module efficiency $15.1 \%$, open circuit voltage $\left(\mathrm{V}_{\mathrm{OC}}\right) 37.5 \mathrm{~V}$, short circuit current $\left(\mathrm{I}_{\mathrm{SC}}\right) 8.8 \mathrm{~A}$, maximum power voltage $\left(\mathrm{V}_{\mathrm{MPP}}\right) 30.5 \mathrm{~V}$ and a maximum power current ( $\mathrm{I}_{\mathrm{MPP}}$ ) of $8.2 \mathrm{~A}$. Furthermore, the inverter efficiency is considered to be $96 \%$. The electricity production analysis includes a minimum installed power of $1.0 \mathrm{~kW}$ with an increasing step of $0.5 \mathrm{~kW}$ and a maximum value of $4.0 \mathrm{~kW}$ (Table 6). The installation is connected to the grid on a "fixed price" contract and a feed-in tariff [43] as this reflects the Greek market for electricity production in the residential building sector. The analysis is completed by an additional scenario with no electricity production and a zero installed power. The case study reference building has zero installed power of PV. 
Table 5. Difference in the total energy demand (heating, cooling and DHW) between the case study reference building and the alternative combinations of energy efficiency measures (insulation and window glazing).

\begin{tabular}{ccccccccc}
\hline $\begin{array}{c}\text { Difference in Total Energy } \\
\text { Demand (kWh/m } \mathbf{2} \cdot \mathbf{a})\end{array}$ & & \multicolumn{7}{c}{ Window Glazing } \\
\hline Insulation Thickness (m) & $\mathbf{W 1}$ & $\mathbf{W}$ & $\mathbf{W 3}$ & $\mathbf{W 4}$ & $\mathbf{W 5}$ & $\mathbf{W 6}$ & $\mathbf{W 7}$ & W8 \\
\hline 0.03 & 30.51 & 29.96 & 25.49 & 26.41 & 25.86 & 24.11 & 23.48 & 22.48 \\
0.04 & 20.28 & 19.74 & 15.02 & 16.04 & 15.49 & 13.63 & 12.93 & 11.93 \\
0.05 & 13.30 & 12.76 & 7.82 & 8.95 & 8.40 & 6.45 & 5.66 & 4.67 \\
0.06 & 8.17 & 7.64 & 2.54 & 3.74 & 3.20 & 1.17 & 0.33 & -0.66 \\
0.07 & 3.13 & 2.59 & -2.69 & -1.41 & -1.95 & -4.06 & -5.00 & -5.98 \\
0.08 & 0.01 & -0.53 & -5.89 & -4.58 & -5.13 & -7.27 & -8.25 & -9.22 \\
0.09 & -3.31 & -3.85 & -9.33 & -7.97 & -8.52 & -10.71 & -11.72 & -12.69 \\
0.10 & -5.29 & -5.82 & -11.37 & -9.99 & -10.54 & -12.75 & -13.79 & -14.77 \\
0.12 & -9.31 & -9.84 & -15.52 & -14.09 & -14.64 & -16.91 & -17.99 & -18.96 \\
0.14 & -12.22 & -12.75 & -18.53 & -17.06 & -17.60 & -19.91 & -21.04 & -22.01 \\
\hline
\end{tabular}

Table 6. Energy efficiency measures. Annual electricity production from photovoltaic panels.

\begin{tabular}{cccc}
\hline Installed Power $\mathbf{( k W )}$ & Number of Modules & PV Area $\left.\mathbf{( m}^{\mathbf{2}}\right)$ & Electricity Production $\mathbf{( k W h / a )}$ \\
\hline 1.0 & 4.0 & 6.6 & 1420.89 \\
1.5 & 6.0 & 9.9 & 2097.31 \\
2.0 & 8.0 & 13.2 & 2785.59 \\
2.5 & 10.0 & 16.5 & 3444.97 \\
3.0 & 12.0 & 19.8 & 4141.71 \\
3.5 & 14.0 & 23.1 & 4812.77 \\
4.0 & 16.0 & 26.4 & 5471.66 \\
\hline
\end{tabular}

Concerning the energy efficiency measures, their combination to every possible way leads to a final number of $10 \times 8 \times 8=640$ variants.

The case study reference building is also analysed for three different fuels: gas, oil and electricity [44]. The current minimum requirements and values of system's efficiencies for the heating, the cooling and the DHW (Domestic Hot Water) equipment along with the national primary energy factors (PEFs) (Table 7) according to the Greek Regulation for the Energy Efficiency of buildings [39], provide the building's fuel and electricity consumption along with their transformation into primary energy.

Table 7. Scenarios of HVAC systems, fuels, system efficiencies and primary energy factors.

\begin{tabular}{ccccc}
\hline Scenario & System & Fuel & Efficiency & Primary Energy Factor \\
\hline \multirow{3}{*}{1} & Heating & Gas & 0.812 & 1.05 \\
& Cooling & Electricity & 2.790 & 2.90 \\
& DHW & Gas & 0.794 & 1.05 \\
& Production & Electricity (PV) & 0.960 (inverter) & 2.90 \\
\hline \multirow{2}{*}{2} & Heating & Oil * & 0.812 & 1.10 \\
& Cooling & Electricity * & 2.790 & 2.90 \\
& DHW & Oil * & 0.794 & 1.10 \\
& Production & Electricity (PV) & 0.960 (inverter) & 2.90 \\
\hline \multirow{2}{*}{3} & Heating & Electricity & 2.980 & 2.90 \\
& Cooling & Electricity & 2.790 & 2.90 \\
& DHW & Electricity & 0.980 & 2.90 \\
& Production & Electricity (PV) & 0.960 (inverter) & 2.90 \\
\hline
\end{tabular}


These minimum efficiencies refer to the total efficiency of the system including production, distribution and terminal units. For scenarios 1 and 2 (Table 7), have been taken into consideration the same reference heating-DHW (boiler-burner, radiators, piping, circulator pump) and cooling (air to air heat pump) systems, with a differentiation limited to the fuel (oil and gas). Even though a gas boiler provides an increased efficiency in reference to an oil boiler, the oil and gas systems in the current study follow the values of the minimum/reference efficiencies according to the Greek Regulation for the Energy Efficiency of buildings [39]. Scenario 3 (Table 7) is composed of an air to air heat pump for the heating and the cooling of the building and an electric boiler for domestic hot water. The electricity production system for all three scenarios consists of photovoltaic panels, with a $96 \%$ efficiency of the inverter and no further losses considered.

\subsubsection{Life Cycle Assessment (LCA)}

In the building industry, life cycle assessment is a method used for the quantification of the environmental impact through the life cycle of a building "as a more mature environmental tool" [45] and with a framework defined by ISO 14040 [30], ISO 14044 [31] and ISO 14025 [32]. The current analysis follows a cradle to grave approach in order to assess the total environmental impact during the lifespan of the building and within the boundaries of its system (Figure 5), as indicated by EN 15978 [46] and EN 15804 [47].

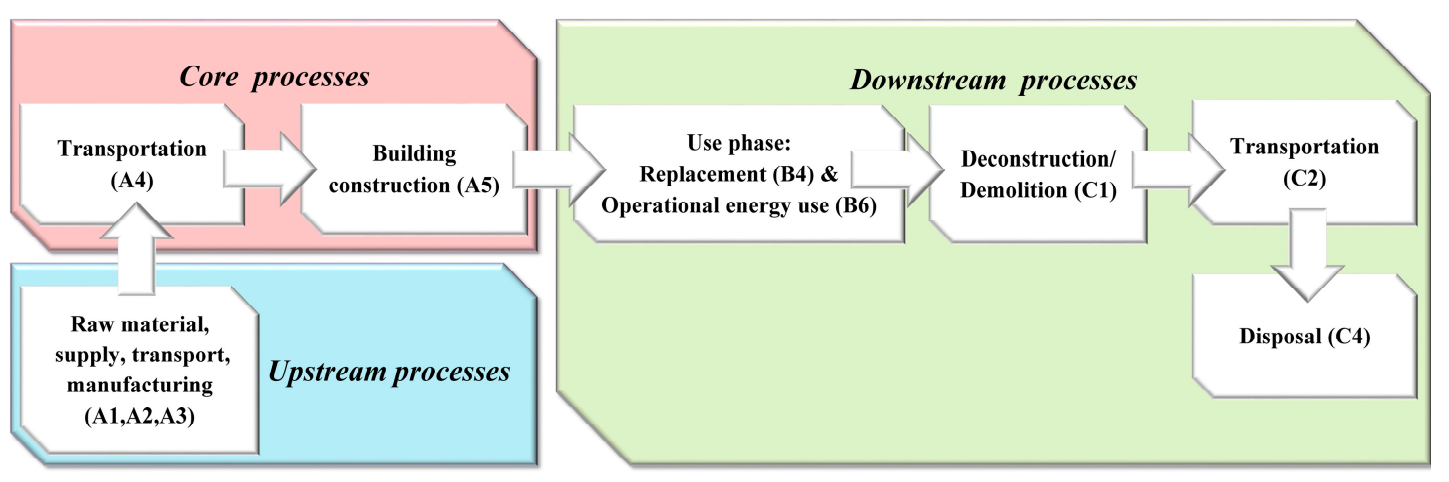

Figure 5. Life cycle processes and boundaries of the system.

Specifically, the Global Warming Potential Effect (GWP-100a) in kg of carbon dioxide emissions equivalent $\left(\mathrm{kg} \mathrm{CO}_{2} \mathrm{e}\right)$ of method CML (Centrum voor Milieuwetenschappen) 2 Baseline 2000 v.2.05 [48], is the selected indicator for the quantification of the environmental impact. Life Cycle Inventory (LCI) data derive from the environmental impact as calculated in a building element level for the SYNERGY 2011 project database [49], where the SYNERGY 2011 project was a national research program with a primary goal to develop a database for the analysis of high energy efficiency building elements by their additional analysis through life cycle assessment. Environmental impact database is based on LCA calculations through software Sima Pro v.7.3.3 [50] and Ecoinvent v.2.2 database [51]. Every necessary additional information comes from the international literature [52-54] and the Environmental Product Declaration (EPD) system [55]. The information related to the EPD system refer to single-company product-specific EPD's [56-60]. The use of international LCI data from the Ecoinvent database and also from EPD's due to lack of a comprehensive Greek LCI database indicates potential uncertainties in the final results.

For the case study reference building, a life cycle assessment for the total quantities and materials of the whole building construction and for every variant by excluding only the final wall decorations and coatings in kitchens and bathrooms, and the sanitary and electrical equipment and plumbing that are not related to the energy efficiency of the building, provides the total environmental impact. Moreover, the drawings of the building provide the bill of quantities (Table 8) for the upstream (A1-A3), replacement (B4) and end of life processes (C4). 
Table 8. Bill of quantities range, LCA information and LCI data for the variants of the building.

\begin{tabular}{|c|c|c|c|c|c|}
\hline Materials \& Components & Unit & $\underset{(\min / \max )^{1}}{\text { Quantity }^{1}}$ & $\begin{array}{l}\text { Transportation } \\
\text { A4/C2 (km) }{ }^{2}\end{array}$ & $\begin{array}{l}\text { Reference Service } \\
\text { Life (years) }\end{array}$ & $\begin{array}{c}\text { Waste Factor } \\
(\%)\end{array}$ \\
\hline Plaster [49] & $\mathrm{kg}$ & $37,581.48$ & $20 / 25$ & 40 & 10 \\
\hline Mortar [49] & $\mathrm{kg}$ & 5212.20 & $20 / 25$ & 40 & 10 \\
\hline Internal paint [59] & $\mathrm{kg}$ & 241.89 & $20 / 25$ & 10 & 7 \\
\hline External paint [58] & $\mathrm{kg}$ & 212.77 & $20 / 25$ & 10 & 7 \\
\hline Concrete [49] & $\mathrm{kg}$ & $224,807.94$ & $20 / 25$ & 100 & 10 \\
\hline Brick [49] & $\mathrm{kg}$ & $61,797.24$ & $15 / 25$ & 90 & 10 \\
\hline Glass fiber [49] & $\mathrm{kg}$ & 41.67 & $20 / 25$ & 30 & 7 \\
\hline XPS [49] & $\mathrm{kg}$ & $355.54 / 1466.18$ & $70 / 25$ & 40 & 7 \\
\hline Adhesives [49] & $\mathrm{kg}$ & 1522.69 & $20 / 25$ & 50 & 0 \\
\hline Steel (reinforcing) [49] & $\mathrm{kg}$ & 9036.78 & $30 / 25$ & 100 & 7 \\
\hline HDPE [49] & $\mathrm{kg}$ & 57.51 & $20 / 25$ & 30 & 7 \\
\hline Gravel [49] & $\mathrm{kg}$ & $15,843.60$ & $40 / 25$ & 80 & 10 \\
\hline Poor concrete [49] & $\mathrm{kg}$ & $17,807.04$ & $20 / 25$ & 80 & 10 \\
\hline Ceramic tiles [49] & $\mathrm{kg}$ & 2629.82 & $1400 / 25$ & 50 & 10 \\
\hline Bitumen [49] & $\mathrm{kg}$ & 601.72 & $20 / 25$ & 30 & 7 \\
\hline Argon [49] & $\mathrm{kg}$ & $0.00 / 0.99$ & $8 / 25$ & 25 & 0 \\
\hline PVC profile [49] & $\mathrm{kg}$ & 137.17 & $8 / 25$ & 50 & 10 \\
\hline Flat glass [56] & $\mathrm{kg}$ & $686.50 / 1028.25$ & $8 / 25$ & 25 & 0 \\
\hline Glass (low-e) [57] & $\mathrm{kg}$ & $0.00 / 342.75$ & $8 / 25$ & 25 & 0 \\
\hline Wood (Oak) [49] & $\mathrm{kg}$ & 1130.40 & $30 / 25$ & 50 & 7 \\
\hline MDF [49] & $\mathrm{kg}$ & 343.80 & $30 / 25$ & 60 & 7 \\
\hline PV panels [49] & $\mathrm{kg}$ & $0.00 / 319.52$ & $2000 / 25$ & 30 & 7 \\
\hline Heating \& DHW system $\left(\right.$ Scen. ${ }^{3} 1$ \& 2) $[49,53]$ & $\mathrm{kg}$ & $345.00 / 465.00$ & $700 / 25$ & 25 & 6 \\
\hline Electronics [49] & $\mathrm{kg}$ & $0.00 / 85.00$ & $2000 / 25$ & 15 & 6 \\
\hline Galvanized steel [60] & $\mathrm{kg}$ & $0.00 / 160.00$ & $30 / 25$ & 40 & 5 \\
\hline Inverter [49] & $\mathrm{kg}$ & $0.00 / 37.00$ & $2000 / 25$ & 15 & 5 \\
\hline Cooling System (Scen. 1, 2, 3) [49] & $\mathrm{kg}$ & 131.09 & $2000 / 25$ & 20 & 10 \\
\hline Heating \& DHW system (Scen. 3) [54] & $\mathrm{kg}$ & 251.09 & $700 / 25$ & 25 & 6 \\
\hline Demolition \& Site restoration [49] & $\mathrm{m}^{3}$ & $591.74 / 629.24$ & $\mathrm{~N} / \mathrm{A} / \mathrm{N} / \mathrm{A}^{4}$ & & $\mathrm{~N} / \mathrm{A}$ \\
\hline Electricity(A5) ${ }^{5}[52]$ & $\mathrm{kWh}$ & $16,938.00$ & N/A/N/A & $\mathrm{N} / \mathrm{A}$ & $\mathrm{N} / \mathrm{A}$ \\
\hline
\end{tabular}

For the transportation processes (A4 and C2) a Euro 4 lorry and transportation with a train were considered for a distance below and over $800 \mathrm{~km}$ respectively. For the materials/components that are produced by local Greek factories, the exact transportation distance was calculated for their transportation to the construction site. Concerning the ceramic tiles these are considered to be imported from Italy $(1400 \mathrm{~km})$ and the electricity production and the cooling systems from Germany $(2000 \mathrm{~km})$. The data for the construction process (A5) of the building derived from the literature [52] and also from personal contact with local contractors in the city of Thessaloniki. For the construction (A5) and replacement (B4) processes waste factors were applied from the literature [61-64] and also from estimations for the Greek construction activity. A reference service life for every material and component $[55,65,66]$, along with the initial impact provided the estimation of the replacement process (B4) related environmental impacts. The demolition, the deconstruction of the building and the restoration of the site are performed by a hydraulic digger and a skid steer loader as this appears to be the common practice indicated by local contractors for single-family residential buildings. The end of life process reflects a worst case scenario with the disposal of all demolition waste in a landfill located $25 \mathrm{~km}$ away from the construction site. For the current framework, three different time periods define the applicable timeframe. Specifically, even though the lifespan of a building could reach 80-100 years, these time periods include a 30 year calculation period based on the recast of the European Directive 2010/31/EE [1], a 50-year calculation period based on the Product Category Rule for Buildings PCR 2014:02 [67] and a 60 year calculation period based on the framework of Building Sustainability Assessment Tools [14,21].

The operational energy for the use phase (B6) was calculated as described in the previous (Section 2.2.1 Energy Analysis) in primary energy ( $\mathrm{kWh}$ ), along with the transformation of the energy and fuel consumption to carbon dioxide $\left(\mathrm{CO}_{2}\right)$ emissions (Table 9). 
Table 9. National Greek fuel $\mathrm{CO}_{2}$ emission factors [39].

\begin{tabular}{cc}
\hline Fuel & $\mathrm{CO}_{2}$ Emission Factor \\
\hline Gas & 0.196 \\
Oil & 0.264 \\
Electricity & 0.989 \\
\hline
\end{tabular}

\subsubsection{Life Cycle Cost (LCC) Analysis}

Life cycle costing "is a methodology for systematic economic evaluation of life cycle costs over a period of analysis, as defined in the agreed scope" [66]. In particular, for the building sector, the method is used for the estimation of the total costs through the life cycle of a building. In the recast of the European Directive 2010/31/EE, life cycle costing follows the Net Present Value (NPV) method for the calculation of the initial (material, labour, construction and design costs), the recurring (running, replacement, energy and emission costs) and the end of life (disposal) costs, along with additional guidance through EN 15459 [68]. In the current case study, the costs considered for the macroeconomic calculations are described in detail in Table 10. Furthermore, the design costs are estimated to be $50 \%$ (local construction market trend) of the minimum cost, as indicated by the Technical Chamber of Greece, for the design and construction supervision of the case study building. The material, transportation, labour, replacement and demolition costs derived from a Greek database [69] used for the cost estimation of building construction related public works. The database costs were updated and validated with offers from local contractors, factories and construction material retailers, for an accurate estimation of the current market policy and prices.

The running costs are considered to be $3 \%$ of the initial investment cost for the HVAC equipment and installations [68]. The energy and fuel costs reflect the market prices at the end of 2015 [70-72], as the starting year of the calculation period is 2016. The emission costs follow the different scenarios for carbon prices [2,3]. The disposal cost is the entrance fee per ton of the untreated construction and demolition waste in a landfill located $25 \mathrm{~km}$ away from the construction site at the suburbs of Thessaloniki.

Table 10. Costs for the macroeconomic global cost calculations.

\begin{tabular}{cc}
\hline Cost Category & Cost Type \\
\hline \multirow{3}{*}{ Initial } & Design \\
& Material \\
& Transportation to the construction site \\
& Energy for construction \\
Labour
\end{tabular}

\subsection{Method}

In the European Union, the European Directive 2010/31/EE (EPBD recast), the delegated regulation 244/12 and the accompanying guidelines define the framework for nearly zero energy buildings. An extended framework provides guidance for the calculation of the global costs for the financial and macroeconomic perspectives, the cost-optimal levels and the definition of the nZEB by the member states towards the goal of 2020. The global cost calculations follow the net present 
value (NPV) method for the discounting of future costs into present costs at the starting year of the calculation period. That specific framework defines the calculations of the initial and the recurring costs and provides an optional consideration of the disposal costs at the end of the building's life cycle. The macroeconomic perspective considers the environmental impact of the operating phase of the building with the calculation and transformation of the annual greenhouse gas emissions into monetary values, indicating the current Commission projected Emission Trading System (ETS) prices per ton of $\mathrm{CO}_{2}$ equivalent as a base value. The calculations of the global costs and for the macroeconomic perspective follow in the next two equations:

$$
C_{g}(\tau)=C_{I}+\sum_{j}\left[\sum_{i=1}^{\tau}\left(C_{a, i(j)} \times R_{d(i)}+C_{c, i(j)}\right)-V_{f, \tau(j)}\right],
$$

and:

$$
R_{d(p)}=\left(\frac{1}{1+\frac{r}{100}}\right)^{p},
$$

where:

$\tau$ is the calculation period in years

$C_{g}(\tau)$ is the global cost (referred to the starting year $\tau 0$ ) over the calculation period in euro

$C_{I}$ is the initial investment cost for measure or set of measures $j$ in euro

$C_{a, i(j)}$ is the annual (running, energy and replacement) cost during year $i$ for measure or set of measures $j$ in euro

$R_{d(i)}$ is the discount factor for year $i$ based on the discount rate $r$ to be calculated

$p$ is the number of years from the starting period

$r$ is the real discount rate

$V_{f, \tau(j)}$ is the residual value of measure or set of measures $j$ at the end of the calculation period (discounted to the starting year $\tau 0$ ) in euro and

$C_{c, i(j)}$ is the carbon cost of measure or set of measures $j$ during year $i$ in euro.

For the macroeconomic calculations, the prices considered are prices excluding all applicable taxes, VAT (Value Added Tax), charges and subsidies. The methodological framework followed in the current case study consists of two steps:

- Step 1. Global cost calculation for the macroeconomic perspective, as defined in the recast of the European Directive 2010/31/EE, the delegated Regulation 244/2012 and the accompanying guidelines.

- Step 2. Global cost calculation for the macroeconomic perspective, with the extension of the emission costs and the consideration of carbon emissions for the whole life cycle of the building.

\subsubsection{Step 1}

In the first step, the global costs for the macroeconomic perspective refer only to the carbon costs of the operating phase of the building. The global costs through the cost categories of the previous (Section 2.2.3 Life Cycle Cost Analysis) and Table 10 are calculated for every variant of the building, for the total cost of the construction and for a square meter of the reference area. The reference service life (Table 8) of each material and component defines the year that a replacement cost takes place and along with the calculation period provide the final residual value. The avoided costs from the produced renewable energy are included as earnings in an annual base even though this option is "best suited" for the financial perspective [3]. A "fixed price" contract with the Hellenic Power Transmission Regulator [43] is considered with the assumption of "only" a feed-in tariff of $0.115 €$ per $\mathrm{kWh}$ of produced electricity. For the reference scenario (Table 11), the discount rate is set at $3 \%$ in real terms and the calculation period starting from the year 2016 at 30 years. The evolutions of energy and carbon prices follow the scenarios and trends provided by the delegated regulation 244/2012. 
Table 11. Basic parameters and values for the reference (Re) scenario.

\begin{tabular}{cc}
\hline Parameter & Value \\
\hline Calculation period $(\tau)$ & 30 years \\
Starting year $(\tau 0)$ & 2016 \\
Discount rate $(r)$ & $3.0 \%$ \\
Gas price & $0.050 €$ \\
Oil price & $0.053 €$ \\
Electricity price & $0.1557 €$ \\
Feed-in tariff & $0.115 €$ \\
Evolution of energy prices & $2.8 \%$ \\
Carbon price, year 2020 & $16.5 €$ \\
Carbon price, year 2025 & $20.0 €$ \\
Carbon price, year 2030 & $36.0 €$ \\
Carbon price, year 2035 & $50.0 €$ \\
Carbon price, year 2040 & $52.0 €$ \\
Carbon price, year 2045 & $51.0 €$ \\
Carbon price, year 2050 & $50.0 €$ \\
\hline
\end{tabular}

The calculation of primary energy is conducted for the energy and fuel consumptions, efficiencies and primary energy factors for every variant of the building (Tables 3, 4 and 7) along with the subtraction of the produced energy from renewable energy sources (Table 6). Even though the produced energy from photovoltaic panels that is fed to the grid is a part of the primary energy balance [2], in the delegated regulation 244/2012 there is no reference for the benefit and the avoided emissions from the production of electricity from renewable energy sources. The current case study considers this benefit as a suitable approach on a macroeconomic scale and the avoided emissions match the emissions produced during the consumption of one $\mathrm{kWh}$ of electricity (Table 9). The final result of the first step is the definition of the cost-optimal level.

\subsubsection{Step 2}

The second step, for the global costs and the macroeconomic perspective, considers the carbon emissions for the whole life cycle of the building. A life cycle assessment for every process within the boundaries of the system (Figure 5) provides an estimation of the total environmental impact in $\mathrm{kg}$ $\mathrm{CO}_{2}$ equivalent. Every emission is calculated and placed in the specific year of the calculation period, transformed into monetary values through the carbon price scenarios, added to the carbon costs of the operating phase and discounted to the starting year of the calculation period:

$$
C_{g}^{\prime}(\tau)=C_{I}+\sum_{j}\left[\sum_{i=1}^{\tau}\left(C_{a, i(j)} \times R_{d(i)}+C_{c, i(j)}^{\prime}\right)-V_{f, \tau(j)}\right]
$$

and:

where:

$$
C_{c, i(j)}^{\prime}=C_{c, i(j)}+C_{c e m b, i(j)}
$$

$C_{g}^{\prime}(\tau)$ is the global cost (referred to the starting year $\tau 0$ ) over the calculation period in euro, for the total life cycle assessment, including the embodied and operating carbon costs

$C_{c, i(j)}$ is the carbon cost of measure or set of measures $j$ during year $i$ in euro, from the operation of the building

$C_{c e m b, i(j)}$ is the embodied carbon cost of measure or set of measures $j$ during year $i$ in euro and

$C_{c, i(j)}^{\prime}$ is the carbon cost of measure or set of measures $j$ during year $i$ in euro, from the total life cycle of the building.

After the global cost calculations, the cost-optimal range and the economic cost-optimal level are redefined and compared with the results of the first step. 


\subsubsection{Sensitivity Analysis}

The Delegated Regulation 244/2012 and the accompanying guidelines define the obligation for a sensitivity analysis of the key parameters, such as the discount rate and evolution of energy prices, along with other parameters that their future development could influence the final result [2]. For the sensitivity analysis on the discount rate, a value of 3\% is indicated for the macroeconomic calculation and at least two additional values should be examined. In the current analysis, two additional discount rates of $2 \%$ and $4 \%$ are considered in real terms (Table 12). The economic crisis in Greece initiated an average annual decrease of $-2.32 \%$ in the construction costs since 2011 [73] and justified the need for an additional sensitivity scenario. Carbon prices are analysed for two additional scenarios [2] and the evolution of energy prices for a 50\% increase and a 50\% decrease in the reference scenario values. Sensitivity analysis is completed by using three alternative values for the calculation period: a 30 year calculation period based on the recast of the European Directive 2010/31/EE, a 50-year calculation period based on the Product Category Rule for Buildings PCR 2014:02 and a 60 year calculation period based on the framework of BSATs. The different scenarios of the analysis (Table 13) are examined for each of the selected values of discount rate and calculation period (Table 12) and for both steps of the procedure.

Table 12. Key parameters and values for the sensitivity analysis.

\begin{tabular}{|c|c|c|c|c|c|c|}
\hline \multicolumn{3}{|c|}{ Parameter } & \multicolumn{4}{|c|}{ Sensitivity Value } \\
\hline \multirow{4}{*}{\multicolumn{3}{|c|}{$\begin{array}{c}\text { Discount rate } \\
\text { Evolution of energy prices } \\
\text { Evolution of construction and } \\
\text { labour prices } \\
\text { Calculation period }\end{array}$}} & \multirow{2}{*}{$\begin{array}{l}2.0 \% \\
1.87 \%\end{array}$} & \multicolumn{2}{|c|}{$3.0 \%$ * } & $4.0 \%$ \\
\hline & & & & \multicolumn{2}{|c|}{$2.8 \%$ * } & $4.2 \%$ \\
\hline & & & \multicolumn{3}{|c|}{$0.0 \%$ * } & \\
\hline & & & 30 years * & & ears & 60 years \\
\hline \multicolumn{7}{|c|}{ Evolution of Carbon Prices } \\
\hline 2020 & 2025 & 2030 & 2035 & 2040 & 2045 & 2050 \\
\hline $16.5 € *$ & $20.0 €$ & $36.0 €$ & $50.0 €$ & $52.0 €$ & $51.0 €$ & $50.0 €$ \\
\hline $25.0 €$ & $38.0 €$ & $60.0 €$ & $64.0 €$ & $78.0 €$ & $115.0 €$ & $190.0 €$ \\
\hline $25.0 €$ & $34.0 €$ & $51.0 €$ & $53.0 €$ & $64.0 €$ & $92.0 €$ & $147.0 €$ \\
\hline
\end{tabular}

Table 13. Sensitivity analysis scenarios. Different scenarios for the evolution of the key parameters.

\begin{tabular}{cccc}
\hline Scenario & \multicolumn{3}{c}{ Values } \\
\cline { 2 - 4 } & $\begin{array}{c}\text { Evolution of Energy } \\
\text { Prices (\%) }\end{array}$ & $\begin{array}{c}\text { Evolution of } \\
\text { Construction Costs (\%) }\end{array}$ & $\begin{array}{c}\text { Evolution of Carbon } \\
\text { Prices ( }(\text { ) }\end{array}$ \\
\hline $\mathbf{R e}^{\mathbf{1}}$ & 2.80 & 0.00 & $16.5-50.0$ \\
$\mathbf{L p r}^{2}$ & 2.80 & -2.32 & $16.5-50.0$ \\
$\mathbf{H C O}_{2}{ }^{3}$ & 2.80 & 0.00 & $25.0-190.0$ \\
$\mathbf{M C O}_{2}{ }^{4}$ & 2.80 & 0.00 & $25.0-147.0$ \\
Len $^{5}$ & 1.87 & 0.00 & $16.5-50.0$ \\
Hen $^{6}$ & 4.20 & 0.00 & $16.5-50.0$ \\
\hline
\end{tabular}

${ }^{1}$ Re: Reference scenario; ${ }^{2}$ Lpr: Decrease in construction and labour prices; ${ }^{3} \mathrm{HCO}_{2}$ : High evolution of carbon prices; ${ }^{4} \mathrm{MCO}_{2}$ : Medium evolution of carbon prices; ${ }^{5}$ Len: Low evolution of energy prices; ${ }^{6}$ Hen: High evolution of energy prices.

\section{Results and Discussion}

The global costs were recalculated as the difference between the global costs of the reference building and the building's variants and for the each step of the procedure (Tables 14-16) with the horizontal axis indicating the global costs (zero difference) for the reference building (Figure 6). 


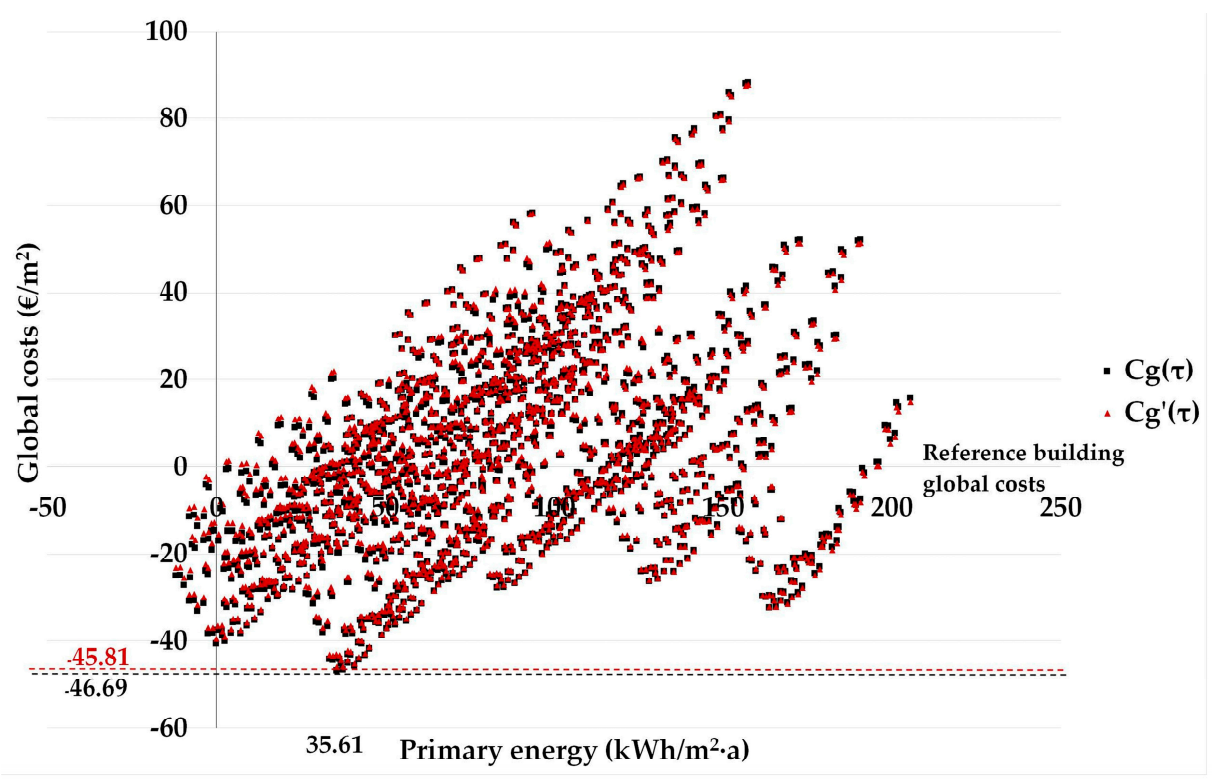

Figure 6. Global costs and cost-optimal level for the reference $(\operatorname{Re})$ scenario. Step $1\left(C_{g}(\tau)\right)$ and step 2 $\left(C^{\prime} g(\tau)\right)$.

For the reference scenario the global costs of the cost optimal level (step 1, $C_{g}(\tau)$ ) are $1285.83 € / \mathrm{m}^{2}$, with a primary energy at $35.61 \mathrm{kWh} / \mathrm{m}^{2}$. annually and a difference of $-46.69 € / \mathrm{m}^{2}$ from the reference building's global costs (Figure 6). The cost-optimal level reflects a $10 \mathrm{~cm}$ thickness of insulation layer, fenestration (W6, Table 4, PVC frame and low-e 6 glazing/12argon/6 glazing) with an average $\mathrm{Uw}=1.76\left(\mathrm{~W} / \mathrm{m}^{2} \cdot \mathrm{K}\right)$, a $4.0 \mathrm{~kW}$ installation of photovoltaic panels for electricity production and the use of electricity (scenario 3, Table 7). The cost-optimal level of the total LCA approach (step 2) and the reference scenario matches the results of the first step. The global costs of the second step $\left(C^{\prime}{ }_{g}(\tau)=1305.26 € / \mathrm{m}^{2}\right)$ indicate an increase of $1.5 \%$ in reference to the global costs of the first step and a difference from the reference building's global costs (of step 2) at $-45.81 € / \mathrm{m}^{2}$ (Figure 6).

Table 14. Sensitivity analysis. Macroeconomic calculations. 30 year calculation period. Cost-optimal.

\begin{tabular}{|c|c|c|c|c|c|c|c|}
\hline \multicolumn{8}{|c|}{ Step 1} \\
\hline \multicolumn{8}{|c|}{ Discount Rate (\%) } \\
\hline & & \multicolumn{2}{|l|}{$2.0 \%$} & \multicolumn{2}{|c|}{$3.0 \%$} & \multicolumn{2}{|c|}{$4.0 \%$} \\
\hline \multicolumn{2}{|c|}{ Scenarios } & $\mathrm{PE}^{1}\left(\mathrm{kWh} / \mathrm{m}^{2} \cdot \mathrm{a}\right)$ & $C_{g}(\tau)^{2}(€)$ & $\mathrm{PE}\left(\mathrm{kWh} / \mathrm{m}^{2} \cdot \mathrm{a}\right)$ & $C_{g}(\tau)(€)$ & PE $\left(\mathrm{kWh} / \mathrm{m}^{2} \cdot \mathrm{a}\right)$ & $C_{g}(\tau)(€)$ \\
\hline \multirow{6}{*}{ Scenario } & $\operatorname{Re}$ & -0.06 & -57.82 & 35.61 & -46.69 & 40.91 & -40.01 \\
\hline & Lpr & -0.06 & -58.17 & 35.61 & -46.99 & 40.91 & -40.27 \\
\hline & $\mathrm{HCO}_{2}$ & -0.06 & -89.67 & -0.06 & -67.33 & 37.60 & -50.93 \\
\hline & $\mathrm{MCO}_{2}$ & -0.06 & -78.01 & -0.06 & -57.77 & 37.60 & -47.10 \\
\hline & Len & 35.61 & -61.16 & 37.60 & -51.92 & 40.91 & -45.03 \\
\hline & Hen & -0.06 & -66.33 & -0.06 & -47.67 & -0.06 & -32.52 \\
\hline \multicolumn{8}{|c|}{ Step 2} \\
\hline \multicolumn{8}{|c|}{ Discount Rate (\%) } \\
\hline & & \multicolumn{2}{|l|}{$2.0 \%$} & \multicolumn{2}{|c|}{$3.0 \%$} & \multicolumn{2}{|c|}{$4.0 \%$} \\
\hline \multicolumn{2}{|c|}{ Scenarios } & $\mathrm{PE}\left(\mathrm{kWh} / \mathrm{m}^{2} \cdot \mathrm{a}\right)$ & $C_{g}^{\prime}(\tau)^{3}(€)$ & $\mathrm{PE}\left(\mathrm{kWh} / \mathrm{m}^{2} \cdot \mathrm{a}\right)$ & $C_{g}^{\prime}(\tau)(€)$ & $\mathrm{PE}\left(\mathrm{kWh} / \mathrm{m}^{2} \cdot \mathrm{a}\right)$ & $C_{g}^{\prime}(\tau)(€)$ \\
\hline \multirow{6}{*}{ Scenario } & $\operatorname{Re}$ & -0.06 & -56.71 & 35.61 & -45.81 & 40.91 & -39.44 \\
\hline & Lpr & -0.06 & -57.06 & 35.61 & -46.11 & 40.91 & -39.71 \\
\hline & $\mathrm{HCO}_{2}$ & -0.06 & -87.91 & -0.06 & -65.64 & 37.60 & -49.83 \\
\hline & $\mathrm{MCO}_{2}$ & -0.06 & -76.31 & -0.06 & -57.77 & 37.60 & -45.99 \\
\hline & Len & 35.61 & -60.28 & 37.60 & -51.17 & 40.91 & -44.47 \\
\hline & Hen & -0.06 & -65.22 & -0.06 & -47.67 & -0.06 & -31.46 \\
\hline
\end{tabular}

${ }^{1}$ PE: Primary Energy; ${ }^{2} C_{g}(\tau)$ : Global costs (step 1$) ;{ }^{3} C_{g}^{\prime}(\tau)$ : Global costs (step 2). 
The embodied environmental impact appears to have no influence on the cost-optimal level for the reference scenario and also for every scenario of the sensitivity analysis for the 30 year calculation period (Table 14), as there is no transposition for the primary energy levels of the cost-optimal level when the embodied impact is considered. The low contribution of the emission costs to the total global costs with the highest value of $4.6 \%$ for the first step and the lowest discount rate of $2 \%$, along with the short calculation period of 30 years and the offsite benefit from the avoided emissions through electricity production from renewable energy sources, could justify this result. The effect of the embodied impact is located at low discount rates of $2 \%$ and $3 \%$ (shaded cells of Tables 15 and 16), where the future costs, including the recurring emission costs, have higher contribution in the total global costs and in combination with an increase in carbon prices $\left(\mathrm{HCO}_{2}\right.$ scenario, shaded cells of Table 16) or even a decrease in other cost categories, such as the construction costs (Lpr scenario, shaded cells of Table 16) and the energy prices (Len scenario, shaded cells of Table 15), enhance the influence of carbon emissions. A transposition to variants with lower use of materials and lower embodied impact is indicated for the three aforementioned scenarios, with a decrease in the number of panes from triple (W8, Table 4) to double glazing (W6, Table 4) for the $\mathrm{HCO}_{2}$ scenario (shaded cells of Table 16) and a decrease in the insulation thickness from $10 \mathrm{~cm}$ to $9 \mathrm{~cm}$ and from $14 \mathrm{~cm}$ to $12 \mathrm{~cm}$ for the Len scenario (shaded cells of Table 15) and the Lpr scenario (shaded cells of Table 16) respectively. For the Hen scenario, the 50 year calculation period and the $2 \%$ discount rate, the increase of energy prices leads to a transposition of the cost-optimal level to variants with higher insulation thickness and lower primary energy and also to a sensitivity range between $-0.06 \mathrm{kWh} / \mathrm{m}^{2}$. annually (Re, step 1 , Table 15) and $-7.91 \mathrm{kWh} / \mathrm{m}^{2}$.annually (Hen, step 1, Table 15) for the first step of the calculation procedure.

Table 15. Sensitivity analysis. Macroeconomic calculations. 50 year calculation period. Cost-optimal.

\begin{tabular}{|c|c|c|c|c|c|c|c|}
\hline \multicolumn{8}{|c|}{ Step 1} \\
\hline \multicolumn{8}{|c|}{ Discount Rate (\%) } \\
\hline & & \multicolumn{2}{|c|}{$2.0 \%$} & \multicolumn{2}{|c|}{$3.0 \%$} & \multicolumn{2}{|c|}{$4.0 \%$} \\
\hline \multicolumn{2}{|c|}{ Scenarios } & $\mathrm{PE}^{1}\left(\mathrm{kWh} / \mathrm{m}^{2} \cdot \mathrm{a}\right)$ & $C_{g}(\tau)^{2}(€)$ & $\mathrm{PE}\left(\mathrm{kWh} / \mathrm{m}^{2} \cdot \mathrm{a}\right)$ & $C_{g}(\tau)(€)$ & $\mathrm{PE}\left(\mathrm{kWh} / \mathrm{m}^{2} \cdot \mathrm{a}\right)$ & $C_{g}(\tau)(\boldsymbol{\epsilon})$ \\
\hline \multirow{6}{*}{ Scenario } & $\operatorname{Re}$ & -0.06 & -85.02 & -0.06 & -57.35 & -0.06 & -36.85 \\
\hline & Lpr & -2.35 & -89.41 & -0.06 & -60.06 & -0.06 & -38.79 \\
\hline & $\mathrm{HCO}_{2}$ & -2.35 & -185.50 & -0.06 & -130.37 & -0.06 & -91.04 \\
\hline & $\mathrm{MCO}_{2}$ & -0.06 & -152.56 & -0.06 & -106.57 & -0.06 & -73.41 \\
\hline & Len & -0.06 & -73.05 & 35.61 & -52.72 & 40.91 & -45.35 \\
\hline & Hen & -7.91 & -113.69 & -2.35 & -76.51 & -0.06 & -50.42 \\
\hline \multicolumn{8}{|c|}{ Step 2} \\
\hline \multicolumn{8}{|c|}{ Discount Rate (\%) } \\
\hline & & \multicolumn{2}{|c|}{$2.0 \%$} & \multicolumn{2}{|c|}{$3.0 \%$} & \multicolumn{2}{|c|}{$4.0 \%$} \\
\hline \multicolumn{2}{|c|}{ Scenarios } & $\mathrm{PE}\left(\mathrm{kWh} / \mathrm{m}^{2} \cdot \mathrm{a}\right)$ & $C_{g}^{\prime}(\tau)^{3}(€)$ & $\mathrm{PE}\left(\mathrm{kWh} / \mathrm{m}^{2} \cdot \mathrm{a}\right)$ & $C_{g}^{\prime}(\tau)(€)$ & $\mathrm{PE}\left(\mathrm{kWh} / \mathrm{m}^{2} \cdot \mathrm{a}\right)$ & $C_{g}^{\prime}(\boldsymbol{\tau})(\boldsymbol{\epsilon})$ \\
\hline \multirow{6}{*}{ Scenario } & $\operatorname{Re}$ & -0.06 & -82.34 & -0.06 & -55.14 & -0.06 & -34.98 \\
\hline & Lpr & -2.35 & -86.57 & -0.06 & -57.85 & -0.06 & -36.92 \\
\hline & $\mathrm{HCO}_{2}$ & -2.35 & -178.90 & -0.06 & -125.49 & -0.06 & -87.13 \\
\hline & $\mathrm{MCO}_{2}$ & -0.06 & -147.31 & -0.06 & -102.41 & -0.06 & -70.01 \\
\hline & Len & -0.06 & -70.36 & 37.60 & -50.92 & 40.91 & -44.17 \\
\hline & Hen & -2.35 & -110.80 & -2.35 & -74.17 & -0.06 & -48.54 \\
\hline
\end{tabular}

${ }^{1}$ PE: Primary Energy; ${ }^{2} C_{g}(\tau)$ : Global costs $(\operatorname{step~} 1) ;{ }^{3} C_{g}^{\prime}(\tau)$ : Global costs (step 2).

The embodied emissions in the second step minimize the sensitivity range between $-0.06 \mathrm{kWh} / \mathrm{m}^{2}$.annually (Re, step 2, Table 15) and $-2.35 \mathrm{kWh} / \mathrm{m}^{2}$.annually (Hen, step 2, Table 15) and indicate an alternative variant with lower insulation thickness (transposition from $12 \mathrm{~cm}$ to $10 \mathrm{~cm}$ ), lower embodied impact and higher primary energy for the cost-optimal level. The calculation period appears to be a key parameter for the global cost calculations and the sensitivity range of the primary energy (Figure 7), as the sensitivity range increases between the 30 and the 50 and 60 year calculation period by $19.17 \%$ and $21.01 \%$ respectively and leads to lower primary energy levels. The total sensitivity range of primary energy for all the scenarios and calculation periods of the sensitivity analysis ranges 
between $-11.97 \mathrm{kWh} / \mathrm{m}^{2}$.annually and $40.91 \mathrm{kWh} / \mathrm{m}^{2}$. annually. The results for the 50 year calculation period indicate that the application of the embodied impact leads to a reduction in the sensitivity range (Figure 7).

Table 16. Sensitivity analysis. Macroeconomic calculations. 60 year calculation period. Cost-optimal.

\begin{tabular}{|c|c|c|c|c|c|c|c|}
\hline \multicolumn{8}{|c|}{ Step 1} \\
\hline \multicolumn{8}{|c|}{ Discount Rate (\%) } \\
\hline & & \multicolumn{2}{|l|}{$2.0 \%$} & \multicolumn{2}{|c|}{$3.0 \%$} & \multicolumn{2}{|c|}{$4.0 \%$} \\
\hline \multicolumn{2}{|c|}{ Scenarios } & $\mathrm{PE}^{1}\left(\mathrm{kWh} / \mathrm{m}^{2} \cdot \mathrm{a}\right)$ & $C_{g}(\tau)^{2}(€)$ & $\mathrm{PE}\left(\mathrm{kWh} / \mathrm{m}^{2} \cdot \mathrm{a}\right)$ & $C_{g}(\boldsymbol{\tau})(\boldsymbol{\epsilon})$ & $P E\left(k W h / m^{2} \cdot a\right)$ & $C_{g}(\tau)(\boldsymbol{\epsilon})$ \\
\hline \multirow{6}{*}{ Scenario } & $\operatorname{Re}$ & -0.06 & -119.99 & -0.06 & -77.71 & -0.06 & -48.78 \\
\hline & Lpr & -11.97 & -128.15 & -0.06 & -81.15 & -0.06 & -51.17 \\
\hline & $\mathrm{HCO}_{2}$ & -2.35 & -245.80 & -0.06 & -165.46 & -0.06 & -111.60 \\
\hline & $\mathrm{MCO}_{2}$ & -0.06 & -205.03 & -0.06 & -137.13 & -0.06 & -91.32 \\
\hline & Len & -0.06 & -101.38 & 35.61 & -69.37 & 37.60 & -55.04 \\
\hline & Hen & -11.97 & -181.33 & -7.91 & -109.35 & -0.06 & -68.66 \\
\hline \multicolumn{8}{|c|}{ Step 2} \\
\hline \multicolumn{8}{|c|}{ Discount Rate (\%) } \\
\hline & & \multicolumn{2}{|l|}{$2.0 \%$} & \multicolumn{2}{|c|}{$3.0 \%$} & \multicolumn{2}{|c|}{$4.0 \%$} \\
\hline \multicolumn{2}{|c|}{ Scenarios } & $\mathrm{PE}\left(\mathrm{kWh} / \mathrm{m}^{2} \cdot \mathrm{a}\right)$ & $C_{g}^{\prime}(\tau)^{3}(€)$ & $\mathrm{PE}\left(\mathrm{kWh} / \mathrm{m}^{2} \cdot \mathrm{a}\right)$ & $C_{g}^{\prime}(\tau)(\boldsymbol{\epsilon})$ & $\mathrm{PE}\left(\mathrm{kWh} / \mathrm{m}^{2} \cdot \mathrm{a}\right)$ & $C_{g}^{\prime}(\tau)(€)$ \\
\hline \multirow{6}{*}{ Scenario } & $\operatorname{Re}$ & -0.06 & -117.29 & -0.06 & -75.49 & -0.06 & -46.90 \\
\hline & Lpr & -7.91 & -124.29 & -0.06 & -78.93 & -0.06 & -49.29 \\
\hline & $\mathrm{HCO}_{2}$ & -0.06 & -239.09 & -0.06 & -160.54 & -0.06 & -107.66 \\
\hline & $\mathrm{MCO}_{2}$ & -0.06 & -199.73 & -0.06 & -132.94 & -0.06 & -87.90 \\
\hline & Len & -0.06 & -98.68 & 35.61 & -67.41 & 37.60 & -53.59 \\
\hline & Hen & -11.97 & -176.88 & -7.91 & -106.33 & -0.06 & -68.66 \\
\hline
\end{tabular}

${ }^{1}$ PE: Primary Energy; ${ }^{2} C_{g}(\tau)$ : Global costs (step 1$) ;{ }^{3} C_{g}^{\prime}(\tau)$ : Global costs (step 2).

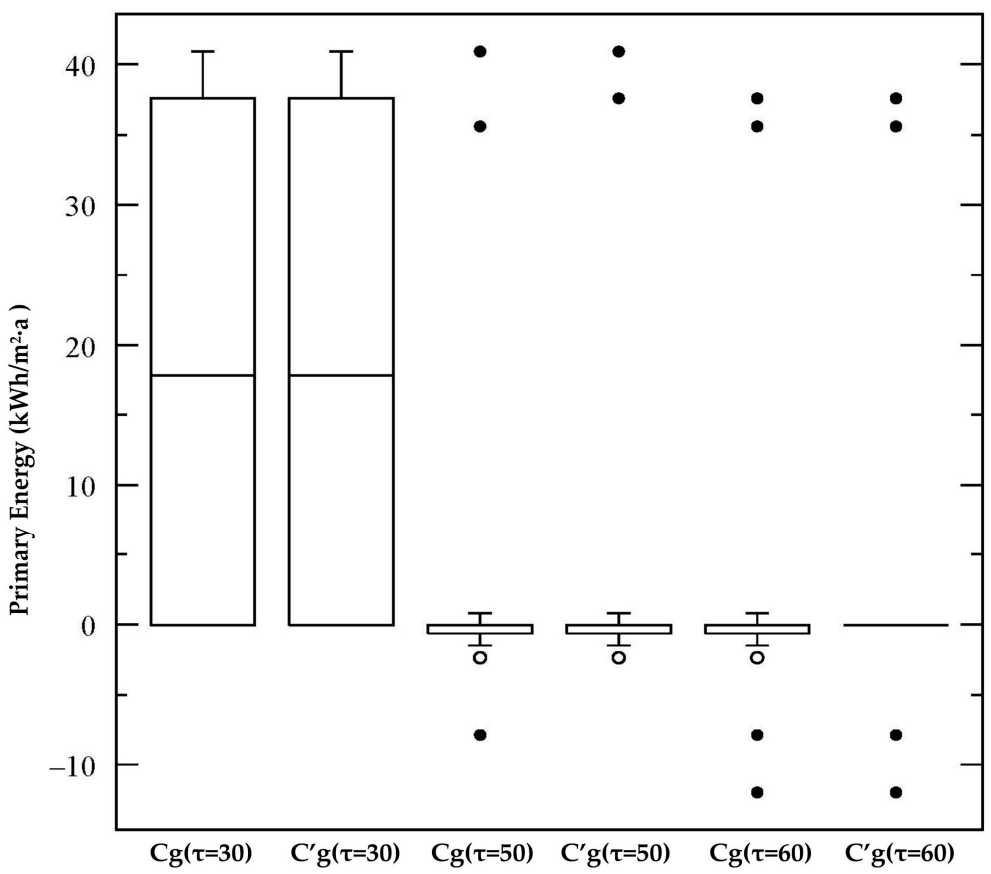

Figure 7. Sensitivity range of primary energy for the cost-optimal level (step $1 C_{g}(\tau)$ ) and step $2\left(C_{g}^{\prime}(\tau)\right)$.

The transposition of the cost-optimal level to higher levels of primary energy with lower insulation thickness, lower number of window panes and lower use of materials is indicated for the 50 and 60 year calculation period (shaded cells of Tables 15 and 16), with the effect of the embodied impact 
located only within the range as calculated through the framework of the current energy efficiency regulations for buildings (step 1, Figure 7). The assumption of "only" a feed-in tariff in the global cost calculations, confirms "a bias at the expense of reduced demand for heating and cooling" [2], considering the current case study assumptions (macroeconomic perspective and a low feed-in tariff). Nevertheless, for the extension of the analysis to higher discount rates (5-7\%), the building variants with a zero installed power of PV (no electricity production) replaced the variants with high installed power of PV for the cost-optimal level. The results of high discount rates are not presented in this paper as they best suit calculations for the financial perspective and further validation is needed.

The limitations of the current case study (building typology, building orientation and climatic conditions) are important. It must be noted that the sensitivity that derives from the LCI data, the reference service life of materials and components, the static methodological approach in reference to the climate and energy mix changes, and also the consideration of "only" a feed-in tariff for the macroeconomic perspective, should not be ignored.

The use of international generic LCI data, as a Greek database is not available, could provide uncertainty in the results and the embodied impact, considering the differentiation in the production processes or even the variation in the electricity production mix [74]. The embodied $\mathrm{CO}_{2}$ emissions for the case study reference building, for the 50 year calculation period and for the cradle to grave approach considered are $958.11 \mathrm{~kg} \mathrm{CO}_{2} \mathrm{e} / \mathrm{m}^{2}$ of the total area (Table 1) of the building. Another case study of Greek single family dwellings [75], that follows a cradle to gate approach and with LCI data from the Inventory of Carbon and Energy database [76], results to embodied $\mathrm{CO}_{2}$ emissions between $871 \mathrm{~kg} \mathrm{CO} 2 \mathrm{e} / \mathrm{m}^{2}$ and $876 \mathrm{~kg} \mathrm{CO}_{2} \mathrm{e} / \mathrm{m}^{2}$ of the total area of the building. When the embodied impact of the current case study reference building was recalculated in a cradle to gate approach, lead to a value for embodied emissions of $555.94 \mathrm{~kg} \mathrm{CO}_{2} \mathrm{e} / \mathrm{m}^{2}$ of the total area of the building, indicating a deviation between the two Greek case studies, deriving probably from the differentiation in the boundaries of the system, the LCI data and the design of the building.

The validation of the results with a global cost calculation for the four main orientations of the case study reference building and for all four climatic areas of Greece, with the extension of the calculations to a multi-family residential building, the potential consideration of embodied energy in the primary energy balance of the building along with a sensitivity analysis on the LCI data and a PV simulation based on net metering as an additional approach that reflects the upcoming trend in the Greek market are of significant importance.

\section{Conclusions}

The current research examines the effect of the embodied environmental impact on the cost-optimal levels of nearly zero energy buildings, with the consideration of the embodied emissions and of a total life cycle approach, as an effort to eliminate the acknowledged "incompleteness" of the assessment defined by the framework of current European energy efficiency regulations. The limited contribution of the emission costs to the total global costs, results to an effect of the embodied environmental impact on the primary energy of the cost-optimal levels only in the sensitivity scenarios with low discount rates of $2 \%$ and $3 \%$ that enhance this contribution along with high carbon, low energy and low construction prices. This effect is located in the extended calculation periods of 50 and 60 years, where the replacements, the recurring embodied impact and the carbon prices are significantly higher in reference to the 30 year calculation period. The application of the embodied emissions results to a decrease between $1.99 \mathrm{kWh} / \mathrm{m}^{2}$.annually and $5.56 \mathrm{kWh} / \mathrm{m}^{2}$. annually in the primary energy of the cost-optimal level and to a transposition to variants with higher primary energy, lower levels of insulation thickness (decrease between $1 \mathrm{~cm}$ and $2 \mathrm{~cm}$ ), lower number of window panes (from triple to double glazing) and consequently to lower embodied environmental impact. The sensitivity range of primary energy increases along with the extension of the calculation period with the highest increase of $21.01 \%$ indicated between the 30 and the 60 year timeframe and confirms its significance as a key parameter that should be considered in the sensitivity analysis as defined by the framework of 
the EPBD recast, the delegated regulation 244/2012 and the accompanying guidelines. Nevertheless, the limitations of the case study indicate the need for further research and validation of the results.

Acknowledgments: This research, including the costs for open access publication, is funded by the Greek State Scholarship Foundation (IKY), under the program "Research Project For Excellence IKY/SIEMENS" and in specific for the project "Investigation of the effect of embodied energy in nearly zero energy buildings-nZEB, in the context of EPBD recast/2010/31/EE and the regulation 244/2012 of the European Union".

Author Contributions: All authors contributed to this research. In specific, the set-up of the methodology, the simulations/calculations, the analysis and the writing of this paper were carried out by Panagiotis Chastas. Karolos J. Kontoleon supported the data analysis and supervised the paper. Theodoros Theodosiou contributed to the building's dynamic energy simulation and its results' analysis. Dimitrios Bikas contributed to the critical editing of the manuscript.

Conflicts of Interest: The authors declare no conflict of interest.

\section{References}

1. Directive 2010/31/EU of the European Parliament and of the Council of 19 May 2010 on the Energy Performance of Buildings (Recast). Available online: http://eur-lex.europa.eu/legal-content/EN/TXT/ PDF/?uri=CELEX:32010L0031\&from=EN (accessed on 15 March 2015).

2. Commission Delegated Regulation (EU) No 244/2012 of 16 January 2012 Supplementing Directive 2010/31/EU of the European Parliament and of the Council on the Energy Performance of Buildings by Establishing a Comparative Methodology Framework for Calculating Cost-Optimal Levels of Minimum Energy Performance Requirements for Buildings and Building Elements. Available online: http:/ / eur-lex. europa.eu/legal-content/EN/TXT/PDF/?uri=CELEX:32012R0244\&from=EN (accessed on 15 March 2015).

3. Guidelines Accompanying Commission Delegated Regulation (EU) No 244/2012 of 16 January 2012 Supplementing Directive 2010/31/EU of the European Parliament and of the Council on the Energy Performance of Buildings by Establishing a Comparative Methodology Framework for Calculating Cost-Optimal Levels of Minimum Energy Performance Requirements for Buildings and Building Elements. Available online: http:/ / eur-lex.europa.eu/legal-content/EN/TXT/PDF/?uri=CELEX:52012XC0419(02) \&from=SK (accessed on 15 March 2015).

4. Karimpour, M.; Belusko, M.; Xing, K.; Bruno, F. Minimising the life cycle energy of buildings: Review and analysis. Build. Environ. 2014, 73, 106-114. [CrossRef]

5. Ramesh, T.; Prakash, R.; Shukla, K.K. Life cycle energy analysis of buildings: An overview. Energy Build. 2010, 42, 1592-1600. [CrossRef]

6. Sartori, I.; Hestnes, A.G. Energy use in the life cycle of conventional and low-energy buildings: A review article. Energy Build. 2007, 39, 249-257. [CrossRef]

7. Chastas, P.; Theodosiou, T.; Bikas, D. Embodied energy in residential buildings-towards the nearly zero energy building: A literature review. Build. Environ. 2016, 105, 267-282. [CrossRef]

8. Thiel, C.L.; Campion, N.; Landis, A.E.; Jones, A.K.; Schaefer, L.A.; Bilec, M.M. A materials life cycle assessment of a net-zero energy building. Energies 2013, 6, 1125-1141. [CrossRef]

9. Cellura, M.; Guarino, F.; Longo, S.; Mistretta, M. Energy life-cycle approach in Net zero energy buildings balance: Operation and embodied energy of an Italian case study. Energy Build. 2014, 72, 371-381. [CrossRef]

10. Stephan, A.; Crawford, R.H. A multi-scale life-cycle energy and greenhouse- gas emissions analysis model for residential buildings. Archit. Sci. Rev. 2014, 57, 39-48. [CrossRef]

11. Hernandez, P.; Kenny, P. Development of a methodology for life cycle building energy ratings. Energy Policy 2011, 39, 3779-3788. [CrossRef]

12. Pombo, O.; Allacker, K.; Rivela, B.; Neila, J. Sustainability assessment of energy saving measures: A multi-criteria approach for residential buildings retrofitting-A case study of the Spanish housing stock. Energy Build. 2016, 116, 384-394. [CrossRef]

13. Hall, M.; Geissler, A.; Burger, B. Two years of experience with a net zero energy balance-Analysis of the Swiss MINERGIE-A standard. Energy Procedia 2014, 48, 1281-1291. [CrossRef]

14. BREEAM International New Construction Technical Manual. Available online: http://www.breeam. com/BREEAMInt2013SchemeDocument/\#09_materials/mat_01_life_cycle_impacts.htm\#kanchor301 (accessed on 26 December 2016). 
15. The Code for Sustainable Homes Setting the Standard in Sustainability for New Homes. Available online: http:/ / webarchive.nationalarchives.gov.uk/20120919132719/www.communities.gov.uk/ documents/planningandbuilding/pdf/codesustainhomesstandard.pdf (accessed on 25 August 2015).

16. DGNB Criterion ECO 1.1 Life Cycle Cost. Available online: http://www.dgnb-system.de/en/system/ criteria/core14/\# (accessed on 25 October 2016).

17. BREEAM Green Guide Online Calculator Tool Guidance. Available online: https://www.bre. co.uk/filelibrary/greenguide/PDF/PN284-Green-Guide-Calculator-Guidance-Jan2015.pdf (accessed on 26 December 2016).

18. DGNB Criterion ENV 2.1 Life Cycle Assessment Primary Energy. Available online: http://www.dgnbsystem.de/en/system/criteria/core14/\# (accessed on 25 October 2016).

19. International Initiative for a Sustainable Built Environment. Available online: http://www.iisbe.org/ sbmethod (accessed on 8 September 2016).

20. JSBC Comprehensive Assessment System for Building Environmental Efficiency (CASBEE) for New Construction-Tecnical Manual. Available online: http://www.ibec.or.jp/CASBEE/english/download/ CASBEE-BD(NC)e_2014manual.pdf (accessed on 25 August 2015).

21. U.S Green Building Council: LEED v4 for Building Design and Construction. Available online: http:/ / www.usgbc.org/resources/leed-v4-building-design-and-construction-current-version (accessed on 10 January 2015).

22. DGNB Criterion ENV 1.3 Responsible Procurement. Available online: http://www.dgnb-system.de/en/ system/criteria/core14/\# (accessed on 25 October 2016).

23. BEAM Plus New Buildings and Existing Buildings. Available online: https://www.hkgbc.org.hk/eng/ BEAMPlus_NBEB.aspx (accessed on 13 September 2016).

24. Green Star Material Calculator Guide. Available online: https://www.google.gr/url?sa=t\&rct=j\&q=\&esrc= s\&source=web\&cd=1\&cad=rja\&uact=8\&ved=0ahUKEwi05bzT_MXLAhXFlnIKHebfBY4QFggbMAA\&url= https\%3A\%2F\%2Fwww.gbca.org.au\%2Fuploads\%2F239\%2F2287\%2FGreen\%2520Star\%2520Material\% 2520Calculator\%2520Guide_v5.pdf\&usg=AFQjCNGW60h9OLzZKW_8PMXUh71FJwBuXA\&sig2= 9SxqqQqTJGAS_M8IHrXiVA\&bvm=bv.117218890,d.bGQ (accessed on 16 August 2016).

25. Lee, B.; Trcka, M.; Hensen, J.L.M. Embodied energy of building materials and green building rating systems-A case study for industrial halls. Sustain. Cities Soc. 2011, 1, 67-71. [CrossRef]

26. Chandratilake, S.R.; Dias, W.P.S. Sustainability rating systems for buildings: Comparisons and correlations. Energy 2013, 59, 22-28. [CrossRef]

27. Andrade, J.; Bragança, L. Sustainability assessment of dwellings-A comparison of methodologies. Civ. Eng. Environ. Syst. 2016, 33, 125-146. [CrossRef]

28. Suzer, O. A comparative review of environmental concern prioritization: LEED vs other major certification systems. J. Environ. Manag. 2015, 154, 266-283. [CrossRef] [PubMed]

29. Sesana, M.M.; Salvalai, G. Overview on life cycle methodologies and economic feasibility for nZEBs. Build. Environ. 2013, 67, 211-216. [CrossRef]

30. International Organization for Standardization. ISO 14040: Environmental Management-Life Cycle Assessment-Principles and Framework; International Organization for Standardization: Geneva, Switzerland, 2006.

31. International Organization for Standardization. ISO 14044: Environmental Management-Life Cycle Assessment-Requirements and Guidelines; International Organization for Standardization: Geneva, Switzerland, 2006.

32. International Organization for Standardization. ISO 14025: Environmental Labels and Declarations-Type III Environmental Declarations_-Principles and Procedures; International Organization for Standardization: Geneva, Switzerland, 2006.

33. Overview of Member States Information on NZEBs-Working Version of the Progress Report-Final Report. Available online: https://ec.europa.eu/energy/sites/ener/files/documents/Updated\%20progress\% 20report\%20NZEB.pdf (accessed on 15 June 2016).

34. Report from the Comission to the European Parliament and the Council-Progress by Member States in Reaching Cost-Optimal Levels of Minimum Energy Performance Requirements. Available online: http:/ / eur-lex.europa.eu/legal-content/EN/TXT/PDF/?uri=CELEX:52016DC0464\&from=EN (accessed on 10 January 2017). 
35. Hellenic Statistical Authority. Available online: http://www.statistics.gr/el/census-buildings-2011 (accessed on 25 August 2015).

36. Technical Guide 20701-3: Climatic Data of Greek Regions. Available online: http:/ / portal.tee.gr/portal/ page/portal/tptee/totee/TOTEE-20701-3-Final-TEE\%203nd\%20Edition.pdf (accessed on 13 February 2015).

37. Greek Regulation for the Energy Efficiency of Buildings (KENAK). Available online: http://portal.tee.gr/ portal/page/portal/tptee/totee/FEK\%20407-B-2010\%20-\%20KENAK.pdf (accessed on 13 February 2015).

38. Energy Plus TM. National Renewable Energy Laboratory. Available online: https://energyplus.net/ (accessed on 12 February 2016).

39. Technical Guide 20701-1: Descriptive national Specifications for the Calculation of the Energy Efficiency of Buildings and the Energy Efficiency Certificate Auditing. Available online: http://portal.tee.gr/portal/ page/portal/tptee/totee/TOTEE-20701-2Final-\%D4\%C5\%C5\%20-\%202nd\%20edition.pdf (accessed on 13 February 2015).

40. Heating Systems in Buildings-Method for Calculation of System Energy Requirements and System Efficiencies-Part 3-2: Domestic Hot Water Systems, Distribution. Available online: http:/ /www.cres.gr/greenbuilding/PDF/prend/set3/WI_11_TC-approval_version_prEN_15316-32_Domestic_hot_water_-_Distribution.pdf (accessed on 20 March 2017).

41. Heating Systems in Buildings-Method for Calculation of System Energy Requirements and System Efficiencies-Part 3-3: Domestic Hot Water Systems, Generation. Available online: http:/ / www.cres.gr/greenbuilding/PDF/prend/set3/WI_11_TC-approval_version_prEN_15316-33_Domestic_hot_water_-_Generation.pdf (accessed on 20 March 2017).

42. Droutsa, K.G.; Kontoyiannidis, S.; Dascalaki, E.G.; Balaras, C.A. Mapping the energy performance of hellenic residential buildings from EPC (energy performance certificate) data. Energy 2016, 98, 284-295. [CrossRef]

43. PV Installations $(\leq 10 \mathrm{~kW})$ in Buildings. Available online: http://www.desmie.gr/ape-sithya/adeiodotikidiadikasia-kodikopoiisi-nomothesias-ape/periechomena/mikra-fotoboltaika-10-kw-se-ktiria/ (accessed on 24 January 2017).

44. Martinopoulos, G.; Papakostas, K.T.; Papadopoulos, A.M. Comparative analysis of various heating systems for residential buildings in Mediterranean climate. Energy Build. 2016, 124, 79-87. [CrossRef]

45. Giama, E.; Papadopoulos, A.M. Assessment tools for the environmental evaluation of concrete, plaster and brick elements production. J. Clean. Prod. 2015, 99, 75-85. [CrossRef]

46. Sustainability of Construction Works-Assessment of Environmental Performance of Buildings-Calculation Method. Available online: https://www.en-standard.eu/csn-en-15978-sustainability-of-constructionworks-assessment-of-environmental-performance-of-buildings-calculation-method/ (accessed on 20 March 2017).

47. Sustainability of Construction Works. Environmental Product Declarations-Core Rules for the Product Category of Construction Products. Available online: https://www.en-standard.eu/csn-en-15804-a1sustainability-of-construction-works-environmental-product-declarations-core-rules-for-the-productcategory-of-construction-products / (accessed on 20 March 2017).

48. CML-IA Database. Available online: https://www.universiteitleiden.nl/en/research/research-output/ science/cml-ia-characterisation-factors (accessed on 25 March 2016).

49. SYNERGY. Research and Development of a System of High Energy-Efficient Building Elements, under Integrated Protection Criteria and Life-Cycle Design Aspects, through the SYNERGASIA 2011; SYNERGY: Thessaloniki, Greece, 2014.

50. Sima Pro Software v.7.3.3. Available online: https://www.pre-sustainability.com/simapro (accessed on 10 May 2014).

51. Ecoinvent Database v.2.2. Available online: http://www.ecoinvent.org/database/older-versions/ecoinventversion-2/ecoinvent-version-2.html (accessed on 10 May 2014).

52. Andersen, S.; Dinesen, J.; Hjort Knudsen, H.; Willendrup, A. Livscyklus-Baseret Bygningsprojektering (Life-Cycle-Based Building Design, Energy and Environment Model, Calculating Tool and Database); Danish Building Research Institute: Hørsholm, Denmark, 1993.

53. Koubogiannis, D.; Nouhou, C. How much Energy is Embodied in your Central Heating Boiler? IOP Conf. Ser. Mater. Sci. Eng. 2016, 161, 1-9. [CrossRef]

54. Piroozfar, P.; Pomponi, F.; Farr, E.R.P. Life cycle assessment of domestic hot water systems: A comparative analysis. Int. J. Constr. Manag. 2016, 16, 109-125. [CrossRef] 
55. International EPD System: Environmental Product Declaration. Available online: http://www.environdec. com/ (accessed on 9 January 2016).

56. EPD Flat Glass, Toughened Safety Glass and Laminated Safety Glass. Available online: http:/ / www.euroglas. com/fileadmin/content/euroglas/Deutsch/Service/Zertifizierungen/EPD_FB_ESG_VSG_Float_EN.pdf (accessed on 25 October 2016).

57. Iplus I Planibel Low-e the Range of AGC Glasses with Thermal Insulation. Available online: http:/ / www. agcnederland.nl/docs/EPD\%20AGC\%20Iplus.pdf (accessed on 25 October 2016).

58. EPD Polisan Exelans Macro External Paint. Available online: http://yesilmalzemeler.com.tr/Content/urunsertifikasi-polisan-exelans-macro-7270013690.PDF (accessed on 25 January 2017).

59. EPD Polisan Natura Ambians Internal Paint. Available online: http://environdec.com/en/Detail/epd739 (accessed on 25 January 2017).

60. EPD-Hot-Dip Galvanized Products. Available online: http://cdn.ruukki.com/docs/default-source/b2bdocuments/epd/en-epd-rc-hot-dip-galvanised.pdf?sfvrsn=20 (accessed on 25 January 2017).

61. Adalberth, K. Energy use during the Life cycle of Single Unit Dwellings: Examples. Build. Environ. 1997, 32, 321-329. [CrossRef]

62. Blengini, G.A. Life cycle of buildings, demolition and recycling potential: A case study in Turin, Italy. Build. Environ. 2009, 44, 319-330. [CrossRef]

63. Blengini, G.A.; Di Carlo, T. The changing role of life cycle phases, subsystems and materials in the LCA of low energy buildings. Energy Build. 2010, 42, 869-880. [CrossRef]

64. Chen, T.Y.; Burnett, J.; Chau, C.K. Analysis of embodied energy use in the residential building of Hong Kong. Energy 2001, 26, 323-340. [CrossRef]

65. Bundesministerium für Umwelt, Naturschutz, Bau und Reaktorsicherheit (BMUB). Nutzungsdauern von Bauteilen, Datenbank Zwischenauswertung; German Federal Ministry for the Environment, Nature Conservation, Building and Nuclear Safety: Berlin, Germany, 2008.

66. International Organization for Standardization. ISO 15686: Buildings And Constructed Assets-Service-Life Planning_Part 5: Life-Cycle Costing; International Organization for Standardization: Geneva, Switzerland, 2008.

67. Product Category Rules according to ISO 14025:2006 Product Group-2014:02. Available online: http:// environdec.com/en/PCR/Detail/?show_login=true\&error=failure\&Pcr=5950 (accessed on 28 May 2015).

68. Energy Efficiency for Buildings-Standard Economic Evaluation Procedure For Energy Systems in Buildings. Available online: http://www.cres.gr/greenbuilding/PDF/prend/set4/WI_29_TC-approval_version_ prEN_15459_Data_requirements.pdf (accessed on 20 March 2017).

69. ATOE-Descriptive Bills of Building Construction Works. Available online: http://www.sate.gr/html/ timologia.aspx (accessed on 16 January 2016).

70. Natural Gas Prices for Household Consumers. Available online: http://ec.europa.eu/eurostat/statisticsexplained/index.php/Natural_gas_price_statistics\#Natural_gas_prices_for_household_consumers (accessed on 10 January 2017).

71. Electricity Prices for Household Consumers. Available online: http://ec.europa.eu/eurostat/statisticsexplained/index.php/Energy_price_statistics\#Electricity_prices_for_household_consumers (accessed on 10 January 2017).

72. Heating Oil Prices. Available online: http://www.popek.gr/index.php/el/times-kafsimon/home (accessed on 10 January 2017).

73. Indicator of New Building Construction Costs. Available online: http://www.statistics.gr/el/statistics/-/ publication/DKT63/ (accessed on 25 August 2015).

74. Dahlstrøm, O.; Sørnes, K.; Eriksen, S.T.; Hertwich, E.G. Life cycle assessment of a single-family residence built to either conventional- or passive house standard. Energy Build. 2012, 54, 470-479. [CrossRef]

75. Syngros, G.; Balaras, C.A.; Koubogiannis, D.G. Embodied CO2 Emissions in Building Construction Materials of Hellenic Dwellings. Proced. Environ. Sci. 2017, 38, 500-508. [CrossRef]

76. Hammond, G.; Jones, C. Inventory of Carbon and Energy: ICE; University of Bath: Bath, UK, 2008.

(C) 2017 by the authors. Licensee MDPI, Basel, Switzerland. This article is an open access article distributed under the terms and conditions of the Creative Commons Attribution (CC BY) license (http:/ / creativecommons.org/licenses/by/4.0/). 